\title{
37. FOSSIL PRESERVATION, GEOCHEMISTRY, AND DIAGENESIS OF PELAGIC CARBONATES FROM SHATSKY RISE, NORTHWEST PACIFIC
}

\author{
Albert Matter, University of Berne, Berne, Switzerland, \\ Robert G. Douglas, University of Southern California, Los Angeles, California \\ and \\ Katharina Perch-Nielsen, Federal Polytechnic Institute, Zürich, Switzerland, and \\ Institut for historic geologi og paleontologi, Kobenhavn, Denmark
}

\section{INTRODUCTION}

The vast scientific effort devoted to the study of the sea floors during the past 20 years has resulted in a rapid increase in our understanding of many aspects of marine sedimentation, including the origin, facies distribution, and diagenesis of marine sediments.

Much of this effort has focused on shallow-water carbonates. Therefore, most ideas about cementation and lithification of carbonate rocks are based on these studies. This explains why, until the mid-1960's, it was generally believed that stabilization (conversion of metastable aragonitic and magnesian-calcitic particles to low magnesian calcite) accompanied by thorough lithification of a carbonate sediment takes place mainly in the subaerial, fresh water, and intertidal environments (Bathurst, 1971, p. 323).

This somewhat biased view had to be revised when, during the past 10 years, more and more examples of both shallow- and deep-water submarine cementation and lithification of carbonate sediments were reported. All examples of lithified carbonates recovered from the deep sea, prior to deep-sea drilling techniques, are lithic layers or crusts which are generally cemented by magnesian calcite (for a detailed review, see Bathurst, 1971; Milliman, 1974).

Studies of pelagic carbonates based on sections drilled by the Deep Sea Drilling Project have documented in situ cementation and lithification of pelagic carbonates which increases with depth of burial and age. The most important sedimentological results gained through DSDP up to 1973 are summarized by Davies and Supko (1973).

In all pelagic carbonate sections drilled by Glomar Challenger, a change from soft ooze to friable chalk to limestone is observed with increasing depth. It is accompanied by an increase in density and seismic velocity and a simultaneous decrease in porosity. These lithologic changes are caused by progressive selective dissolution of the more soluble planktonic foraminifera, delicate coccoliths, and supersoluble micritic carbonate grains. The latter are formed by the breakdown of calcareous skeletons and the dissolved $\mathrm{CaCO}_{3}$ is reprecipitated as overgrowth cement on the more robust discoasters and coccoliths (Matter, 1974; Schlanger and Douglas, 1974). Hence, the large amounts of carbonate necessary to cement a carbonate ooze are not introduced from an outside source, but rather are derived from the surrounding material.

It follows from the overgrowth cementation and the large reduction of porosity with depth observed in the pelagic carbonate sequences that compaction must be important in pelagic carbonates, a point suspected by Tracey et al. (1971), and Cook and Cook (1972), and others. However, because compaction features in micrites have been only rarely observed, gravitational compaction was held negligible in carbonate muds (Pray, 1960; Bathurst, 1971) until recently.

Because foraminiferal tests possess a large intrabiotic void space, their dissolution would result in a large reduction of the porosity of the bulk sediment. Schlanger et al. (1973) and Schlanger and Douglas (1974) have shown that dissolution of foraminifera might indeed account for the entire porosity decrease, from $80 \%$ to $40 \%$, which is observed in the transition of ooze to limestone. They observed that the percentage of broken benthonic foraminifera rapidly increases with depth of burial. Dissolution and subsequent breakdown also affects the tests of planktonic foraminifera. However, because of their greater solubility, fragments of planktonic foraminifera are dissolved, so little evidence of fractured tests is preserved. The paucity of benthonic foraminifers in deep-sea sediments and therefore the relative scarcity of crushed benthonics is another reason why compaction was considered unimportant. On a macroscopic and microscopic scale, compaction also affected shelf coccolith oozes of the Irish and English Chalk (Scholle, 1974; Kennedy and Garrison, in press).

The gross aspects of pelagic carbonate diagenesis have been described. However, many details, such as the influence of siliceous biogenic and terrigenous components, amount of organic matter, water depth, etc, remain to be solved. The operative processes and the interactions of the solids with the interstitial fluids remain almost totally unknown.

In this paper we shall first provide an estimate of the abundance and preservation of foraminifera and nannofossils at Sites 305 and 306. Secondly, we shall discuss the $\mathrm{Ca}^{2+}, \mathrm{Mg}^{2+}$, and $\mathrm{Sr}^{2+}$ distribution in the solids and interstitial waters. Combining all this information and linking it with stable isotope, porosity, and accumulation rate data, we will discuss the downhole evolution of diagenetic textures and provide a quantitative measure for the diagenetic potential.

\section{REGIONAL SETTING AND NATURE OF SEDIMENTS}

The present study is based on the cores recovered during DSDP Leg 32 on Shatsky Rise at Sites 305 and 306. Detailed description and discussion of the structure, stratigraphic relationships, and lithology are given in the 
site chapters in this volume. Here only data pertinent to the diagenesis of the cored sediments are summarized.

Sites 305 and 306 are located on the southern edge of Shatsky Rise, an irregularly shaped, large, elongated plateau in the northwestern Pacific (Figure 1). It trends north-northeast to south-southwest for about $1400 \mathrm{~km}$ and has a maximum width measured northwest-southeast perpendicular to the strike of the feature of about $500 \mathrm{~km}$. It rises more than 2000 meters above the surrounding deep-sea floor, with large parts of the plateau lying in water depths between 3500 and 2000 meters.

Like other elevated plateaus in the Pacific, such as the Ontong-Java and Manihiki plateaus, Magellan and Hess Rise, Shatsky Rise is capped by a thick (close to $1000 \mathrm{~m}$ ) sedimentary cover. Shatsky Rise has been a site of biogenic, mainly carbonate, deposition at least since Late Jurassic time.

The water depth at Site 305 is 2903 meters. The drilling was abandoned at 640.5 meters below the sea floor. Site 306 was drilled on a ledge on the upper slope of the rise, $37 \mathrm{~km}$ to the west-southwest of Site 305, in an area where upper Albian strata crop out. At Site 306 upper Albian sediments are covered only by a thin unconsolidated veneer which contains mixed Albian to Recent faunas. The fauna and presence of a few graded beds indicate that these thin sediments were derived by erosion of older strata which crop out further upslope. Site 306 was abandoned at 475 meters subbottom depth before reaching the crystalline basement.
The lithologic sequences of both sites and the age relationships are shown in Figure 2. The two sections can be correlated both on a litho- and a biostratigraphic basis and are therefore combined into one single composite section (Figure 3 ). The following five different lithologic units are recognized from top to bottom.

\section{Unit 1}

Siliceous foram-rich nanno oozes of early Miocene to Quaternary age occur in the uppermost 52 meters of the section. They consist on the average of $60 \%$ to $80 \%$ nannofossils and foraminiferal tests, $5 \%$ to $20 \%$ siliceous fossils, and a minor terrigenous admixture (Plate 1, Figure 1). The oozes are very soft; the GRAPE porosity decreases from $68 \%$ at the top of the unit to about $60 \%$ at 50 meters depth. Because of large pore spaces, these sediments still appear texturally as a rather loose accumulation of calcareous and siliceous microfossils which have been only moderately affected by dissolution (Plate 1, Figure 1). A hiatus representing part of the early Miocene and late Oligocene was found at the base of this unit.

\section{Unit 2}

An almost pure foraminiferal nanno ooze, ranging in age from late Maestrichtian to late Oligocene, is present from 52 to 148.5 meters. The carbonate content exceeds $95 \%$. These oozes have a pale orange color which is caused by the presence of a small amount of ferroman-

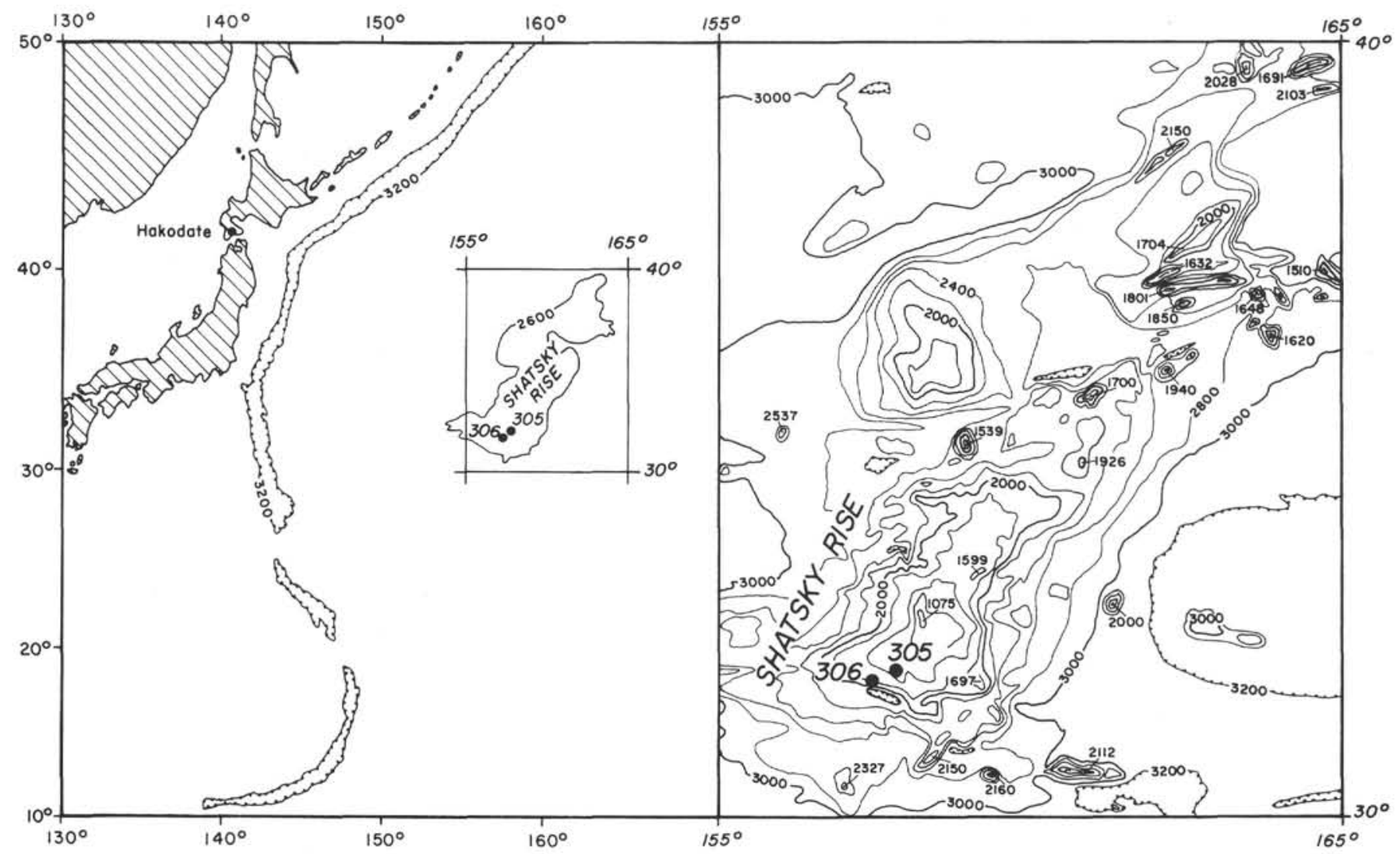

Figure 1. Index map showing the bathymetry of Shatsky Rise and location of drill sites. Simplified contours are in fathoms from map by Chase et al. (1971). 


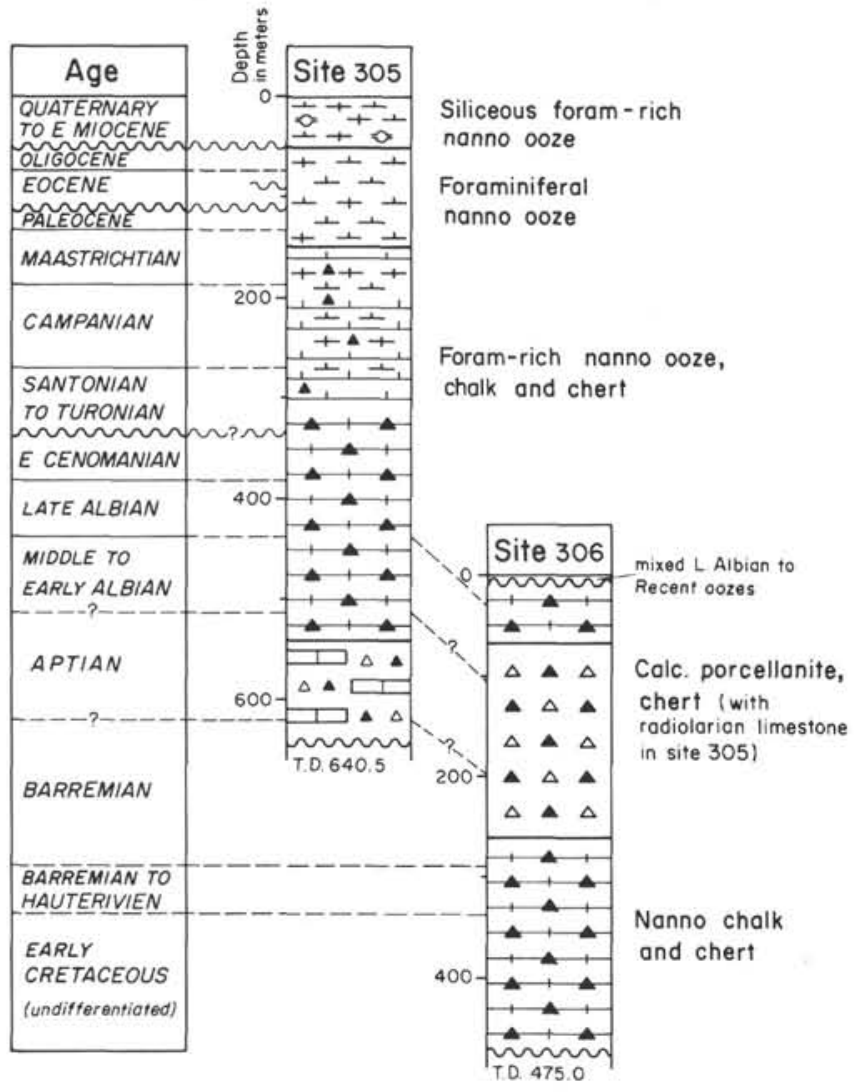

Figure 2. Stratigraphic sequences at Sites 305 and 306. Age correlations are based on the data presented in biostratigraphy chapters (this volume).

ganese oxides. According to Broecker (1974) manganese nodules occur in sediments which have an average accumulation rate of $3 \mathrm{~m} / 10^{6} \mathrm{yr}$. The sediments in the upper half and lower third of Unit 2 accumulated at a rate of about $2 \mathrm{~m} / 10^{6} \mathrm{yr}$ and $4 \mathrm{~m} / 10^{6} \mathrm{yr}$, respectively (Figure 3); low for deep-sea carbonate oozes. The slow rate of accumulation is the major reason for the relatively high concentration of ferromanganese oxides in this unit.

Only minor compositional changes were observed within Unit 2. This unit consists predominantly of calcareous nannofossils with variable minor admixtures of foraminiferal tests and traces of phillipsite and clay minerals. The GRAPE porosity decreases to $50 \%$ at about 125 meters, however, in the lowest part of the unit, it increases slightly to a more or less constant value of $50 \%$ to $55 \%$ (Figure 3 ).

The compositional and textural characteristics of Unit 2 are shown on the SEM micrographs of two samples taken at 86.3 meters and 119.9 meters subbottom depth (Plate 1, Figures 2, 3). Both samples are nannofossil oozes. However, compare the tighter fabric of the deeper sample with the open framework fabric of the shallower one. This difference is expected from the porosities mentioned above. Also, note the abundant isolated distal shields of coccoliths, whose delicate central structures have been dissolved, and the heavy calcite overgrowths, mainly on discoasters.

\section{Unit 3}

Foram-rich nanno ooze, chalk, and chert (Aptian to middle Maestrichtian) comprise this unit. The upper part of this unit consists of alternating soft to stiff ooze and semilithified chalk layers made up of nannofossils and foraminifera in varying proportions (Plate 1, Figure 4). Thin-walled echinoid spines are a typical constituent, in trace amounts, of these sediments. The carbonate content is close to $100 \%$. Chert occurs as irregular stringers and thin layers in the upper part of this section. Notice that the packing of the nanno chalk (shown in Plate 1, Figure 4) is less dense than in the shallower sample shown in Plate 1, Figure 3.

Below 242 meters, only rock fragments were recovered for each 9-meter cored interval. Besides abundant chert pieces, only a few chalk fragments other than chalky void fillings in chert or chalk crusts on chert were retrieved. This explains the lack of control points in Figure 3. Thus, reconstruction of the lithologic sequence remains ambiguous. Most likely the sequence is dominated by chalk with lesser chert nodules or layers.

Below about 365 meters Radiolaria were again observed and silicification becomes more important. The original opaline radiolarian tests are altered and filled mainly with fibrous chalcedony, as are the chambers of foraminifera.

The chalks become harder and more porcellanite-like towards the base of the unit (Plate 1, Figure 5), although the porosity does not change. The rather advanced induration apparently results from the combination of two effects: progressive deposition of carbonate cement and silicification.

\section{Unit 4}

Unit 4 consists of radiolarian limestone, calcareous porcellanite, and chert of Barremian to Aptian/Albian age. This unit was recovered in the lowermost part of Site 305 and at Site 306 (Figure 2). The foram nanno chalks of Unit 3 grade into the radiolarian nanno limestones in Unit 4 by a gradual increase of the abundance of Radiolaria and progressive lithification. The radiolarian opal is replaced by chalcedony, disordered cristobalite, and occasionally by calcite. In the lower part of this unit, walls of the foraminifera are recrystallized and their chambers are filled with one or several large sparry calcite crystals and occasionally some euhedral barite crystals (Plate 2, Figure 6). The fabric of the radiolarian limestones is fairly dense, as shown in Plate 1, Figure 5.

The radiolarian limestones grade into harder porcellanites which is indicated by a decrease in the carbonate content to below $50 \%$, an increase in the silicification, and a minor increase of the clay mineral content. The porcellanites have duller lusters and higher densities than the radiolarian limestones. Plate 2, Figures 1 and 2 are SEM photomicrographs of an acidleached and an untreated fragment of the same sample. About $60 \%$ by weight of the sample is noncarbonate (mainly silica) which was remobilized during diagenesis and reprecipitated partly in the pore space and partly as a replacement of small carbonate particles and fragments of calcareous nannofossils. Only the sturdiest coccoliths escaped silicification. 


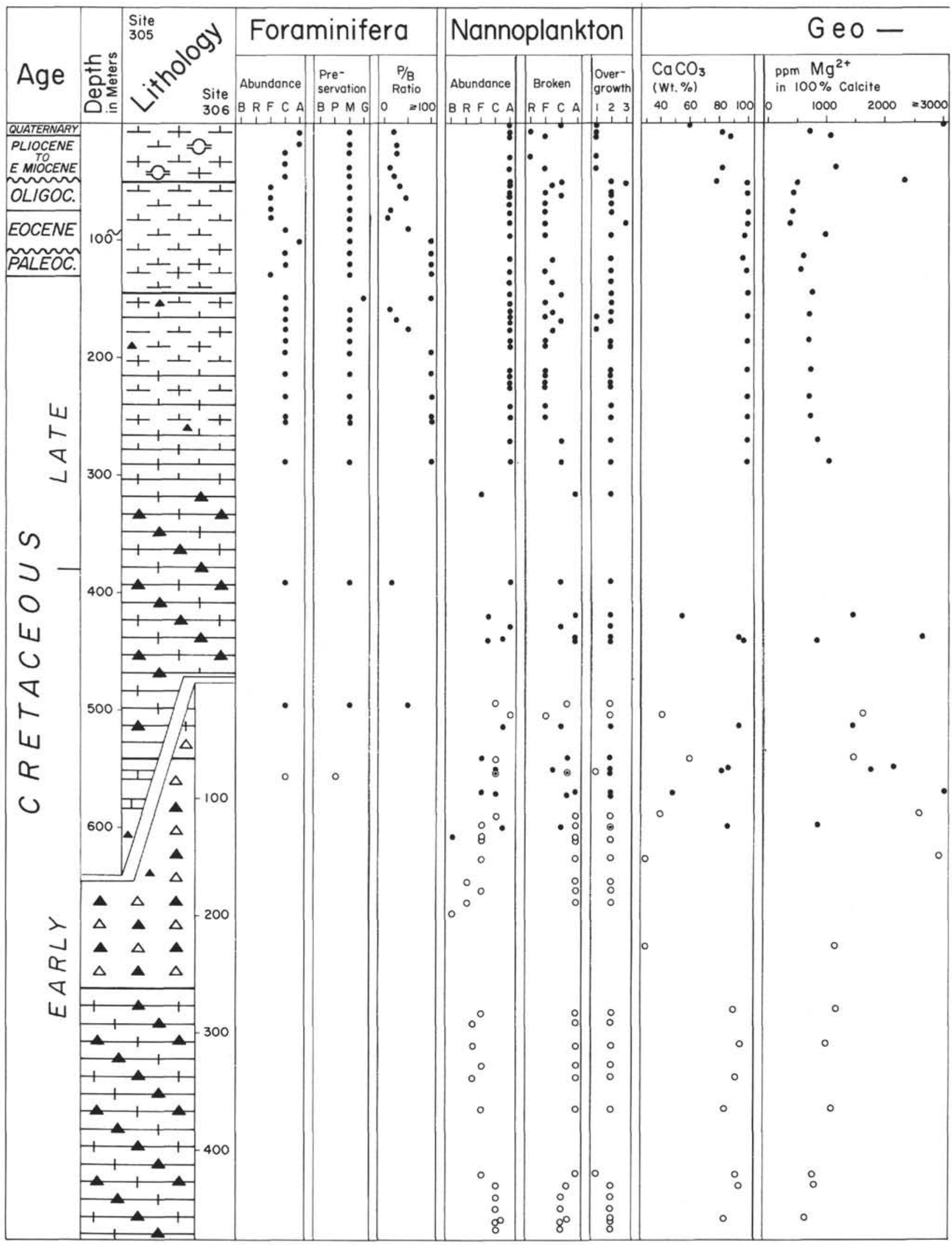

Figure 3. Composite stratigraphic section of Sites 305 and 306 with foraminifera-nannofossil data, geochemical data, porosities, and sedimentation rates. Site 305 is indicated by closed circles, Site 306 by open circles. 


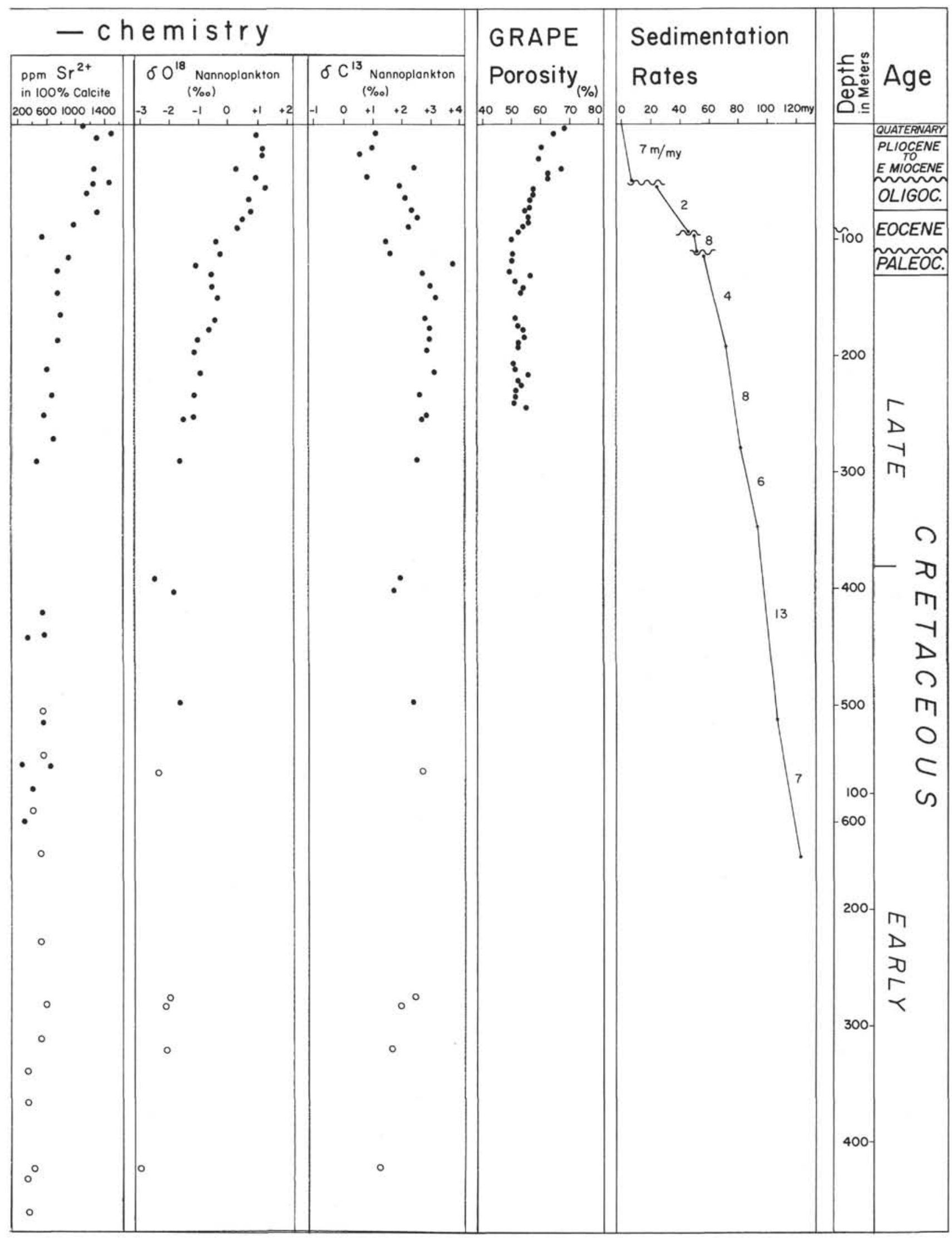

Figure 3. (Continued). 
A more detailed description of the porcellanites and cherts appears in the lithology section of the site chapters and in Keene (this volume).

\section{Unit 5}

Nanno chalk and chert of Early Cretaceous to Barremian age comprise Unit 5 . Because only core-catcher samples containing a few rock fragments were retrieved, it is impossible to construct a reliable lithologic sequence for this unit. Most likely, however, it consists mainly of grayish, faintly laminated, nannofossil chalk with chert nodules and irregular chert layers. Bioturbation, which destroyed the laminations, was frequently noticed.

The chalk is composed of nannofossils, foraminifera, Radiolaria, small amounts of dolomite rhombs (Plate 2, Figure 5), pyrite, and clay minerals. The dolomite crystals, which are frequently twinned, average about 50 microns in size and may be as large as 150 microns. According to X-ray analysis and using the curve of Goldsmith et al. (1961), the average composition of the dolomite is $\mathrm{Ca}_{54} \mathrm{Mg}_{46}\left(\mathrm{CO}_{3}\right)_{2}$.

Plate 2, Figures 3 and 4 , show the textural aspect of the chalks from Unit 5. The packing of the coccoliths, which have accumulated abundant secondary calcite, is fairly dense.

Large calcite crystals tend to overgrow fragments of coccoliths, thereby occluding part of the pore space. Notice that the chalks at the bottom of the hole are less indurated than those in Unit 4 above it.

\section{METHODS OF STUDY}

The samples were studied in smear slides and the results of the visual estimates are shown in Site Report chapters, Sites 305, 306 (this volume). The mineralogy was determined by X-ray diffraction technique and some additional samples were analyzed by Matter. The SEM work on sediment textures was carried out with a Cambridge stereoscan mark IIA instrument at the Geology Department of Berne University, using osmic acid prior to the normal preparatory technique as described previously by Matter, 1974. Abundance of nannofossils, the amount of broken specimens, and the presence of overgrowths were estimated from smear slides, at a magnification of $1000 \times$, and sediment surfaces prepared for the study of sedimentary textures with the SEM. Additional samples were suspended in distilled water and a drop of the suspension was then sedimented on a glass-covered SEM stub, dried, and carbon and gold coated. Ultrasonic and centrifuge treatment, both routine techniques in calcareous nannofossil investigations, were deliberately not used in order to avoid any possible changes of preservation and of the ratio of whole to broken nannofossils.

A total of 40 sediment samples from Sites 305 and 306 was selected for geochemical analysis. The samples were finely ground, stirred for $5 \mathrm{~min}$ in distilled water, and then filtered and washed three times to avoid contamination with pore fluids. One-hundred milligrams from the oven-dried samples were dissolved in $2 N$ hydrochloric acid and immediately filtered after effervescence had stopped. The sample was then diluted to 100 $\mathrm{ml}$ with distilled water.
Calcium was analyzed by EDTA titration using HHSNN as an indicator. Both strontium and magnesium were determined on a Perkin-Elmer Model 303 atomic absorption spectrophotometer using the "standard procedure" recommended for the instrument. The standard solutions were prepared from commercially obtained stock solutions (Merck).

Quadruplicate analyses of a few samples showed that the analytical errors are $\pm 0.2 \%$ for $\mathrm{Ca}^{2+}, \pm 2 \%$ for $\mathrm{Mg}^{2+}$, and $\pm 5 \%$ for $\mathrm{Sr}^{2+}$ by weight. A strontium solution prepared from a NBS $\mathrm{SrCO}_{3}$ standard was analyzed and had a far better precision than the samples.

The techniques used for isotopic analysis of oxygen and carbon are described in Douglas and Savin (this volume). The results are given in per mil deviations $(\delta)$ from the PDB-1 standard.

\section{PRESERVATION OF FOSSILS}

\section{Foraminifera}

Planktonic foraminifera decrease from abundant in the Quaternary and late Pliocene to few in the Oligocene to middle Eocene ( 50 to $80 \mathrm{~m}$ ) (Figure 3 ). In the lower Tertiary the abundance of planktonic foraminifera varies between few to abundant, whereas in the Cretaceous they are generally common.

A qualitative system for fossil preservation, such as the one shown in Figure 3, assesses only the average preservation state of a planktonic foraminiferal assemblage. Hence, the preservation state of the planktonic foraminifera is indicated as moderate throughout the section. However, a detailed inspection reveals differential preservation of different species as well as a range of preservation states within each species. This is in agreement with studies of Recent planktonic foraminiferal assemblages which demonstrate that the tests are selectively dissolved and fragmented.

The ratio of the number of planktonic to benthonic foraminifera is another measure of preservation. Studies of Recent foraminiferal assemblages have shown that this ratio is mainly controlled by selective dissolution of planktonic foraminifera. After burial the planktonic to benthonic foraminiferal ratio is subject to further change as the result of diagenesis. The planktonic to benthonic foraminiferal ratio is low (15 to 25) in Quaternary to middle Miocene sediments. In early Eocene to late Maestrichtian and early Campanian and Santonian sediments the values are around 200 , whereas in middle Maestrichtian sediments they are below 50. The high values found in early Campanian and Santonian sediments may not be reliable because of the very few benthonic foraminifera present. The planktonic to benthonic foraminiferal ratios suggest excellent preservation of the Campanian and lower Maestrichtian, but probably better than actually exists. With increasing lithification, larger numbers of crushed and partly dissolved tests were observed in thin sections and prepared samples (Plate 1, Figure 4). In the Early Cretaceous some benthonic foraminifera are overgrown with chamber infillings of calcite spar and some barite crystals (Plate 2, Figure 6). 


\section{Calcareous Nannofossils}

Optical studies of the nannofossil samples from Sites 305 and 306 are shown in Figure 3 together with the lithological, physical, and geochemical data. At Site 305 calcareous nannofossils are abundant, from the Pleistocene to Santonian, independent of the degree of dissolution of foraminifera. Nannofossils vary from abundant to few in the chert-bearing sequence below the Santonian.

The number of broken specimens is taken as a measure of the degree of dissolution. "Broken coccoliths" in Figure 3 includes coccoliths whose proximal and distal shields (see Figure 4) are detached as well as specimens with broken shields and walls. The number of broken nannofossils is related to lithology and depth of burial at Site 305 . In the first 40 meters broken nannofossils are generally rare. However, in the foraminiferal nanno ooze and the top part of the foram-rich nanno ooze and chalk, they become few to common. Below the chert-bearing sediments of Site 305, broken nannofossils are common to abundant (Figure 3).

The degree of overgrowth on the nannofossils increases with depth of burial. The first 40 meters of sediment show rare overgrowths on nannofossils, whereas deeper in the section secondary calcite is usually important. It must be noted, however, that it is difficult to judge the degree of overgrowth in Quaternary and preupper Paleocene sediments lacking discoasters. Overgrowths are only recognizable in such samples by the occurrence of heavy-appearing dissolution-resistant coccoliths such as Watznaueria barnesae, Micula staurophora, and others. These samples have to be studied with the aid of the SEM to fully evaluate the degree of secondary calcite deposition on coccoliths.

The abundance of coccoliths at Site 306 decreases from abundant in the Cenomanian to Albian chalks to rare or barren in the Barremian to Aptian porcellanites. Coccolith abundance decreases with the decrease in total carbonate content (Figure 3 ). In the nanno chalks below the porcellanites, coccoliths increase in abundance. Often these Cretaceous assemblages contain coccoliths without central structures, and the wall or the shield are overgrown. Rhabdoliths rarely have their shields attached.

The following brief description of selected samples summarizes the observations made with the aid of the SEM.

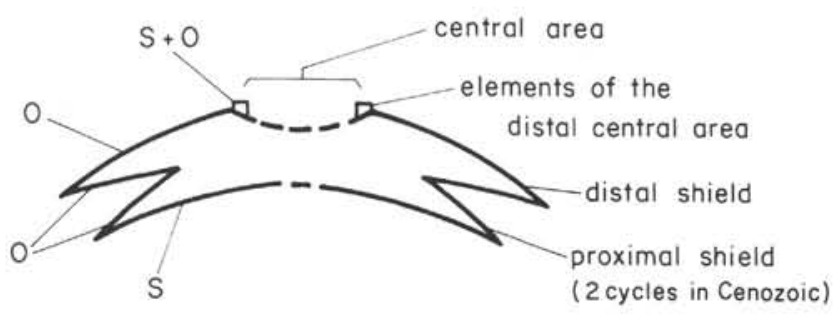

Figure 4. Cross-section of a placolith similar to Watznaueria (Cretaceous), Ericsonia, and Coccolithus (Tertiary) showing major structural features and sites of preferential deposition of overgrowth cement (O) or of dissolution (S).

\section{$305-1-2,20 \mathrm{~cm}$}

The soft ooze contains disaggregated specimens of Emiliania huxleyi and many single-shielded Coccolithus pelagicus and Cyclococcolithus leptoporus. The details of the structure are generally poorly visible. Dissolution is important whereas deposition of overgrowth cement is negligible and diffuse (Plate 3, Figures 1, 2). Poorly preserved diatoms and silicoflagellates are also found.

\section{$305-4-3,140 \mathrm{~cm}$}

The discoasters have accreted some overgrowth cement, but their arms are still slender. Discoaster pentaradiatus shows less overgrowth than Discoaster surculus. Minor amounts of cement were also deposited on a few single elements of the distal shields of coccoliths, whereas proximal shields are etched (Plate 3, Figures 3, 4).

\section{5-6-4, $92 \mathrm{~cm}$}

Discoasters display dissolution and overgrowth (Plate 3 , Figures 5,6). Sphenoliths generally have lost their base due to dissolution, but they have acquired calcite overgrowths on the apical segments or the spine (Plate 3, Figures 7, 8). Distal and proximal shields of the Prinsiaceae are still entirely individualized (Plate 3, Figure 9).

\section{$305-6-5,135 \mathrm{~cm}$}

In the 2-meter interval separating this and the previous sample, a hiatus was found (Figure 2). Optical investigation revealed a marked difference in the preservation between the two samples (Figure 3), which is obvious in the SEM micrographs (compare Plate 3, Figures 5, 6, with Figure 10). Discoasters in Sample 6-5, $135 \mathrm{~cm}$ show thick overgrowths with well-developed crystal faces. Occasionally overgrowth and dissolution etching are coexistent on the same specimen. Sphenoliths have accreted thick calcite overgrowths on proximal as well as on apical elements (Plate 3, Figure 11), but both kinds of elements are found disconnected. Well-preserved proximal shields of Coccolithus pelagicus and Ericsonia ovalis together with partly dissolved ones were observed (Plate 3, Figures 12,13). Generally, the coccoliths from this sample appear to be less affected by dissolution than in the previous sample.

\section{$305-9-3,100 \mathrm{~cm}$}

Surprisingly, many empty specimens of Reticulofenestra umbilica, whose central areas had been dissolved away, were observed in this sample. When well preserved, $R$. umbilica has a very delicate grid that spans the central area. However, the grid can also be overgrown (Perch-Nielsen, 1971, 1972). Proximal and distal shields of Prinsiaceae are either individualized or partly merged. Here, a varying number of elements have grown by calcite accretion and have bridged the intershield space, welding elements of the proximal and distal shield. The proximal shield of Ericsonia ovalis often is incomplete due to dissolution. The elements of the central area of Dictyococcites bisectus show moderate overgrowth. In general, however, discoasters and Isthmolithus recurvus are almost indeterminable because of thick calcite 
overgrowths masking the original structure (Plate 4, Figures 1, 2).

\section{$305-11-4,90 \mathrm{~cm}$}

Almost all discoasters show heavy overgrowths (Plate 4, Figures 3, 7). Considerable amounts of secondary calcite were also deposited on the elements of the central area and on the distal shield of Ericsonia ovalis (Plate 4, Figure 8). Specimens of Campylosphaera dela usually have lost their central cross by dissolution (Plate 4, Figure 6). Chiasmolithus eograndis and other Chiasmolithus, which, when well preserved, display a fine net between the arms of the central cross, have lost this structure in this sample.

\section{$305-13-4,90 \mathrm{~cm}$}

A dissolution-overgrowth pattern similar to that of the previous sample was observed here. Discoaster multiradiatus and some fasciculiths show heavy overgrowth (Plate 4, Figures 9, 10) whereas the proximal shield of Chiasmolithus is mainly affected by dissolution. Ericsonia ovalis clearly demonstrates varying degrees of preservation in the same sample: some specimens are moderately preserved with both shields still connected (Plate 4, Figure 11); others have partly welded proximal and distal shields with segments bridging the intershield space (Plate 4, Figure 9); and other specimens show both dissolution and overgrowth features (Plate 4, Figure 10). A large number of tiny carbonate crystals, ranging from about $0.1 \mu \mathrm{m}$ to a few $\mu \mathrm{m}$ in size, are scattered between broken and whole coccoliths. Schlanger et al. (1973), Matter (1974), and others have shown that these anhedral crystals originate from the disaggregation of coccoliths and foraminifera caused by dissolution. Nannofossil diagenesis in Tertiary sediments at Site 305 consists of: (1) dissolution of delicate coccoliths, the proximal shields and central areas of Prinsiaceae, Chiasmolithus, and other dissolution-resistant forms; (2) deposition of calcite overgrowth cement on discoasters, sphenoliths, and the central areas and distal shields of coccoliths. The pattern of diagenesis changes somewhat in Cretaceous sediments because different types of calcareous nannofossils are present.

\section{$305-16-5,23 \mathrm{~cm}$}

This sample comes from the uppermost chalk layer recovered at Site 305. Many coccoliths are broken and often lack their central structures. Overgrowths occur, in the absence of discoasters and sphenoliths in this Maestrichtian assemblage, mainly on zygoliths' walls and on indeterminable fragments. Micritic crystals are abundant, but no interstitial cement has yet been deposited (Plate 5, Figure 1).

\section{$305-19-2,130 \mathrm{~cm}$}

Specimens lacking a central area are abundant in this sample. The delicate laths of the central process of Stradneria limbicrassa are still well preserved, but the terminal structure on the same process shows heavy overgrowth (Plate 5, Figure 2). A considerable amount of secondary calcite has been deposited on the nannofossils, such as on the central area of Arkhangelskiella cymbiformis, on the distal and proximal shields of Prediscosphaera cretacea which are welded, and on Micula staurophora (Plate 5, Figures 3-5).

\section{5-27, CC}

Preservation in this and the previous sample are similar. For example, Broinsonia parca (Plate 5, Figure 6) shows calcite overgrowths on laths within the central structure. However, coccospheres of Watznaueria barnesae (Plate 7, Figures 1,2) are common. It has been shown by Okada and Honjo (1970) that coccospheres of most species are common in the water column down to about 100 meters and then decrease in abundance until almost none are preserved below 200 meters.

\section{5-31, CC}

With the exception of a slightly more advanced state of overgrowth, the degree of nannofossil preservation in this sample is much the same in Cores 19, 27, and 31 . Micula staurophora, a very dissolution-resistant species is relatively more abundant here than in the other samples. This is an indication that most other more delicate species have been dissolved to a greater extent than in the previous samples perhaps furnishing the carbonate required for the very heavy calcite overgrowths observed on the remaining coccoliths which renders them taxonomically indeterminable (Plate 5, Figure 7).

\section{5-34, CC}

Watznaueria barnesae is almost the only abundant nannofossil species preserved in this chalk sample taken from a coating on a chert nodule (Plate 5, Figure 9). Overgrowths are well developed on the few other resistant species present, such as on the distal part of the central process of Prediscosphaera cretacea (Plate 5, Figure 8 ), whereas the type of central processes which occurs on Eiffellithus turriseiffeli are still void and the laths are thin. Micritic crystals which were anhedral in the younger samples show crystal faces (Plate 5, Figure 9).

\section{5-46, CC}

In contrast to the low diversity encountered in Core 34 , the assemblage in this sample is more diverse due to the decreased effects of dissolution and overgrowth.

\section{$305-59-1,140 \mathrm{~cm}$}

Overgrowth features are prominent in this sample. Almost all shields of Watznaueria barnesae are welded and many euhedral crystals have reached a considerable size. Some of these envelope coccoliths to various degrees, as shown by sutures of coccolith elements exposed on crystal surfaces, yet other overgrowths have grown by deposition of calcite cement on micritic seed crystals (Plate 5, Figures 10-12).

\section{$305-64-1,100 \mathrm{~cm}$}

In this sample the central processes of the Eiffellithus turriseiffeli-type show signs of dissolution and diffuse overgrowth. Disaggregated coccoliths and micrite crystals are abundant, but there is less overgrowth cement than in the previous sample (Plate 5, Figure 13). 
Nannofossil preservation in chalk layers from the porcellanite, chalk, and chert units at Site 306 (Figure 3) is similar to that described at Site 305. An advanced stage of calcite overgrowth development is observed on dissolution-resistant Watznaueria barnesae. Proximal and distal shields are entirely welded (Plate 6, Figure $10)$, and the central areas are filled with secondary calcite (Plate 6, Figure 6). Pressure dissolution features are rare at Sites 305 and 306. An exception is found in the Aptian to Hauterivian chalk of Site 306 (Plate 6, Figure 9).

\section{Molds of Coccoliths}

Molds and replicas of coccoliths are observed in the calcareous porcellanites from Cores 306-3, 6, 8, 9, and 10 (Plate 6, Figures 1 to 5, 7, and 8). Deposition of silica in the pore space and partial silicification of nannofossils has formed a mosaic of opal-CT and quartz which tightly fits the contours of surviving Watznaueria barnesae specimens. Two dissolution episodes are recognized: dissolution seems to predate silicification because many broken coccoliths are observed to have continued after silicification as indicated by molds of entire specimens and of internal parts of partly silicified coccoliths (Plate 6, Figures 2, 4, 7, 8).

In Barremian to Hauterivian sediments from Site 306 dolomite crystals are present which have incorporated relatively well-preserved coccoliths and micritic grains (Plate 6, Figure 11). Coccoliths partly engulfed by dolomite crystal are illustrated on Plate 6, Figure 11 and suggests that the coccoliths were not dissolved during crystallization. We did not determine whether these coccoliths are still unaltered or whether they have been dolomitized.

\section{Preservation of Coccolithus pelagicus-Ericsonia ovalis and Watznaueria barnesae}

We have studied the detailed preservation of Coccolithus pelagicus and Ericsonia ovalis from the Tertiary and Watznaueria barnesae from the Cretaceous of Sites 305 and 306. All three species are dissolution-resistant forms likely to be abundant in deep-sea carbonate sediments. In the Tertiary forms, selective dissolution first attacks the proximal shield, which disintegrates into micrite-sized elements. These tiny particles are preferentially dissolved, because of their small size, during progressive diagenesis until nothing remains of the proximal shield (Plate 1, Figure 2). In these species overgrowth cement is deposited first on single elements and, with progressive diagenesis, on all elements of the distal shield (Plate 3, Figure 13) and central area (Figure 4, Plate 4, Figure 8; Perch-Nielsen, 1972). Calcite cement is preferentially deposited on the proximal side of the distal shield until the two shields are welded. This is the general pattern for placoliths, as shown by Matter (1974). Partly dissolved proximal shields which have been subsequently overgrown, can be found (Plate 4, Figure 10).

In Watznaueria barnesae dissolution removes the elements surrounding the central area (Plate 7, Figures $2,6,7)$. Overgrowth cement may be deposited on the same specimen lacking central areas. The overgrowths appear first on single elements (Plate 6, Figure 7) and then progressively cover the entire shield (Plate 7, Figures 3-5) until the two shields become welded. The same patiern was also recognized on some other species, such as Prediscosphaera cretacea, which have two shields.

\section{Geochemistry}

\section{Calcium}

Variations of the calcium carbonate content of the sediments are closely related to changes in the ratio of calcareous microfossils to siliceous fossils plus diagenetic silica. Other constituents such as terrigenous and authigenic silicates, volcanic glass, and iron oxides occur in very minor amounts. Figure 4 shows the relationship between $\mathrm{HCl}$-leachable calcium, plotted as $\mathrm{CaCO}_{3}$ and lithology. At Site 305 the lowest carbonate content in the uppermost 52 meters corresponds with siliceous foram nanno oozes. The foram nanno ooze and the chalks below it are almost pure carbonate. In the siliceous chalks and calcareous porcellanites, carbonate values range from $50 \%$ to $98 \%$. A similar variation occurs in the siliceous sediments at Site 306 (Table 1).

\section{Magnesium}

In Quaternary to Miocene siliceous foram nanno oozes the values show a range from about 1000 to 5150 $\mathrm{ppm}$ magnesium. Recent planktonic foraminifera contain between 500 to $2400 \mathrm{ppm}$ magnesium (Savin and Douglas, 1973), and coccolith oozes show values ranging from 1500 to $1700 \mathrm{ppm} \mathrm{Mg}^{2+}$ (Milliman, 1974). The anomalously high values exceeding $2000 \mathrm{ppm} \mathrm{Mg}^{2+}$ are caused by magnesium ions which were leached from clay minerals during sample preparation. At 50 meters the magnesium content drops off sharply to $400 \mathrm{ppm}$, the lowest magnesium content found. This change coincides with a lithologic boundary and an unconformity (Figure 2). No further change is observed down to 90 meters. This interval of low values correlates well with the low abundance of planktonic foraminifera.

The chalks and oozes between 100 and 250 meters have a slightly higher magnesium content (600 to 700 $\mathrm{ppm}$ ) which coincides with more abundant planktonic foraminifera. In the lower part of Site 305 and in the upper part of Site 306 the magnesium content of the sediments varies and may reach values exceeding $2000 \mathrm{ppm}$ magnesium. Dolomite crystals were noted in small amounts and may be the source of magnesium in these sediments.

\section{Strontium}

The strontium content of the Neogene sediments ( 0 to $50 \mathrm{~m}$ ) averages about $1300 \mathrm{ppm}$. A sharp decrease from $1300 \mathrm{ppm}$ to about $700 \mathrm{ppm}$ is observed in the midTertiary between 50 and about 100 meters. The decrease correlates with deposition of overgrowth cement on nannofossils which is accompanied by a rapid change in the ratio of carbon and oxygen isotope. Note the coincidence with the lowest accumulation rate found at Site 305. Below 100 meters the strontium content decreases in a regular fashion to about $350 \mathrm{ppm}$ at the bottom of Hole 306 . The progressive lithification is accompanied 
TABLE

Total Carbonate Content and Concentration of Strontium and Magnesium in Sediment Samples from Sites $\mathbf{3 0 5}$ and 306

\begin{tabular}{|c|c|c|c|c|c|c|}
\hline $\begin{array}{c}\text { Sample } \\
\text { (Interval in } \mathrm{cm} \text { ) }\end{array}$ & $\begin{array}{l}\text { Depth } \\
\text { (m) }\end{array}$ & $\begin{array}{l}\mathrm{CaCO}_{3} \\
\text { (wt \%) }\end{array}$ & $\begin{array}{l}\mathrm{Sr}^{2+} \\
(\mathrm{ppm})\end{array}$ & $\begin{array}{c}\mathrm{Sr}^{2+}(\mathrm{ppm}) \\
\text { per } 100 \% \\
\text { calcite }\end{array}$ & $\begin{array}{l}\mathrm{Mg} 2+ \\
(\mathrm{ppm})\end{array}$ & $\begin{array}{c}\mathrm{Mg}^{2+}(\mathrm{ppm} \\
\text { per } 100 \% \\
\text { calcite }\end{array}$ \\
\hline
\end{tabular}

Site 305

$\begin{array}{lccr}1-1,20 & 1.70 & 60.94 & 720 \\ 1-6,140 & 7.90 & 82.87 & 1250 \\ 2-3,30 & 11.30 & 88.4 & 1150 \\ 5-3,50 & 39.00 & 83.47 & 1050 \\ 6-4,92 & 50.42 & 78.37 & 1200 \\ 6-5,135 & 52.35 & 99.29 & 1230 \\ 7-4,100 & 60.00 & 100.09 & 1150 \\ 9-3,100 & 77.00 & 100.19 & 1300 \\ 10-3,130 & 86.3 & 99.59 & 980 \\ 11-4,90 & 96.9 & 98.19 & 530 \\ 13-4,90 & 115.9 & 97.99 & 900 \\ 14-5,120 & 127.2 & 98.96 & 750 \\ 16-5,23 & 145.23 & 99.90 & 750 \\ 18-5,148 & 165.48 & 99.96 & 798 \\ 20, \text { CC } & 186.0 & 99.99 & 750 \\ 23-5,120 & 212.20 & 100.59 & 600 \\ 25, \text { CC } & 233.00 & 100.32 & 670 \\ 27, \text { CC } & 251.50 & 100.9 & 586 \\ 29, \text { CC } & 270.0 & 99.68 & 700 \\ 31, \text { CC } & 289.50 & 91.9 & 400 \\ 44, \text { CC } & 419.0 & 56.55 & 300 \\ 46, \text { CC } & 438.0 & 94.08 & 550 \\ 47-1,128 & 439.28 & 98.38 & 340 \\ 54, \text { CC } & 513.0 & 92.38 & 500 \\ 58, \text { CC } & 550.5 & 88.28 & 220 \\ 59-1,140 & 551.9 & 82.67 & 550 \\ 61-1,135 & 570.8 & 49.34 & 200 \\ 64-1,100 & 599.0 & 87.60 & 280 \\ & & & \end{array}$

Site 306

\begin{tabular}{lllllrr}
$3, \mathrm{CC}$ & 28.0 & 43.09 & 240 & 557 & 694 & 1611 \\
$5, \mathrm{CC}$ & 66.0 & 61.36 & 350 & 570 & 892 & 1454 \\
$8-1,38$ & 113.38 & 41.04 & 180 & 439 & 1061 & 2585 \\
$10-1,69$ & 151.69 & 28.83 & 150 & 520 & 832 & 2885 \\
$14, \mathrm{CC}$ & 226.0 & 30.6 & 160 & 523 & 344 & 1124 \\
$21-1,62$ & 281.62 & 91.08 & 550 & 604 & 1049 & 1152 \\
$24-1,140$ & 310.40 & 97.29 & 530 & 545 & 935 & 961 \\
$26, \mathrm{CC}$ & 337.0 & 94.08 & 340 & 361 & 2834 & 3012 \\
$29, \mathrm{CC}$ & 365.0 & 85.48 & 300 & 350 & 886 & 1037 \\
$36, \mathrm{CC}$ & 421.0 & 92.08 & 400 & 434 & 684 & 743 \\
$37, \mathrm{CC}$ & 430.5 & 93.88 & 330 & 352 & 735 & 783 \\
$40, \mathrm{CC}$ & 459.0 & 84.58 & 320 & 378 & 524 & 620 \\
\hline
\end{tabular}

by a loss of strontium, as shown on Figure 3. The strontium depletion takes place through dissolution of $\mathrm{Sr}^{2+}$. richer skeletal calcite and reprecipitation primarily on nannofossils of an $\mathrm{Sr}^{2+}$-poorer calcite cement. The sediments at the bottom of Hole 306 have a strontium content of about $350 \mathrm{ppm}$ which is in the range of ancient limestones on land (Bathurst, 1971).

\section{Calcium, Magnesium, and Strontium in the Pore Fluids}

The interstitial water samples cover that part of the sequence where compaction and lithification are most pronounced, yet the pore water data (Table 2) show little change. The only compositional differences occur at about 50 meters depth. The significant changes are: (1) Lower $\mathrm{Ca}^{2+}$ and partly lower $\mathrm{Sr}^{2+}$ concentrations in the siliceous foram-rich nanno oozes. (2) An increase in alkalinity and salinity with depth to about 50 meters and then a decrease in alkalinity from 50 to 100 meters. (3) Slight decrease of $\mathrm{Sr}^{2+}$ from 52 to 239 meters. A calculation shows that the differences in alkalinity between samples are caused by different amounts of total dissolved calcium and magnesium. For example, the alkalinities in Cores 3 and 6 differ by $0.73 \mathrm{meq} / \mathrm{kg}$ and the sum of $\mathrm{Ca}^{2+}$ and $\mathrm{Mg}^{2+}$ by 0.4 mmoles/1 which is equivalent to $0.8 \mathrm{meq} / \mathrm{kg}$. Compared with average seawater, $\mathrm{Ca}^{2+}$ is enriched in the pore fluids by about $12 \%$, whereas magnesium is depleted on the average by $5.5 \%$. Strontium, however, whose concentration in average seawater is $8 \mathrm{ppm}$, is enriched by $25 \%$ to $43 \%$ in the interstitial water. Neugebauer (1974) shows that at some drill sites small changes of the concentrations of magnesium and calcium in the pore waters of oozes and 
TABLE 2

Concentrations of Calcium, Magnesium, and Strontium Ions in Pore Fluids From Site 305 and Their Alkalinity and Salinity

\begin{tabular}{|c|c|c|c|c|c|c|c|c|}
\hline $\begin{array}{c}\text { Sample } \\
\text { (Interval in cm) }\end{array}$ & $\begin{array}{c}\text { Depth } \\
\text { (m) }\end{array}$ & $\begin{array}{c}\mathrm{Ca}^{2+} \\
(\mathrm{ppm})\end{array}$ & $\begin{array}{r}\mathrm{Mg}^{2+} \\
(\mathrm{ppm})\end{array}$ & $\begin{array}{c}\mathrm{Sr}^{2+} \\
(\mathrm{ppm})\end{array}$ & $\frac{\mathrm{mMg}^{2+}}{\mathrm{mCa}^{2+}}$ & $\frac{\mathrm{mSr}^{2+}}{\mathrm{mCa}^{2+}} \cdot 10^{-2}$ & $\begin{array}{r}\text { Alkalinity } \\
(\mathrm{meq} / \mathrm{kg})\end{array}$ & $\begin{array}{c}\text { Salinity } \\
(\%)\end{array}$ \\
\hline $1-5,144-150$ & 7.5 & 405 & 1274 & 7.8 & 5.18 & 0.88 & 2.34 & 34.9 \\
\hline $3-2,144-150$ & 20.0 & 405 & 1289 & 10.4 & 5.25 & 1.17 & 2.30 & 35.2 \\
\hline $6-5,144-150$ & 52.5 & 453 & 1270 & 11.5 & 4.62 & 1.16 & 3.03 & 35.5 \\
\hline $11-5,144-150$ & 99.0 & 449 & 1270 & 10.8 & 4.66 & 1.10 & 2.83 & 35.2 \\
\hline $16-5,144-150$ & 146.5 & 453 & 1274 & 10.8 & 4.64 & 1.09 & 2.48 & 35.8 \\
\hline $21-4,144-150$ & 192.0 & 453 & 1282 & 10.3 & 4.66 & 1.04 & 2.48 & 35.5 \\
\hline $26-4,144-150$ & 239.0 & 453 & 1274 & 10.0 & 4.64 & 1.01 & 2.49 & 35.5 \\
\hline
\end{tabular}

Note: Calcium and magnesium data through courtesy of J. B. Keene.

chalks are noticed but large changes occur at other sites. For example, Manheim and Sayles (1971) found pore waters enriched in calcium to over $1200 \mathrm{ppm}$, and in strontium to $119 \mathrm{ppm}$. They also recorded, at the same drill sites, decreases of magnesium to less than $400 \mathrm{ppm}$ with depth. As pointed out by Manheim and Sayles (1971) and Sayles et al. (1974), the departures of calcium, magnesium, and strontium concentrations from those of normal seawater suggest that calcite is dissolved and aicalcite cement containing less strontium and more magnesium is precipitated.

\section{Stable Oxygen and Carbon Isotopes}

The isotopic compositions of nannofossil calcite are plotted versus age in Figure 3. The data from Sites 305 and 306 confirm the general decrease of the $\mathrm{O}^{18}$ content in pelagic carbonates with age, which has been noted on land, and at other DSDP drill sites (Anderson and Schneidermann, 1973; Douglas and Savin, 1971; Coplen and Schlanger, 1973; and Lawrence, 1973). It is critical to the interpretation of oxygen isotope data from biogenic calcite to find out whether the values have subsequently been altered. Oxygen isotope composition of pelagic carbonates may change during diagenesis, but there is no agreement regarding the time and environment of the isotope adjustment. It may occur at the sea floor or during early or late diagenesis.

Lithified pelagic carbonate rocks have been found to be in isotopic equilibrium with the ambient bottom seawater (Milliman, 1966, 1971). These lithified layers occur in nondepositional environments which indicates that lithification and isotopic reequilibration is a slow process at the open oceanic sea floor (Milliman, 1974). Wise and Hsü (1971) described a monospecific semilithified Braarudosphaera chalk of Oligocene age from the South Atlantic. This chalk occurs as thin bands within unconsolidated oozes. The unusually high $\delta \mathrm{O}^{18}$ values (up to $+3.3 \%$ ) of the chalk are interpreted to reflect isotopic adjustment and precipitation of overgrowth cement in equilibrium with cold bottom waters (Wise and Hsü, 1971; Lloyd and Hsü, 1972).

Studies of the isotope composition of a series of samples from several DSDP boreholes revealed a downhole decrease of $\delta \mathrm{O}^{18}$ from generally about $+1 \%$ close to the water-sediment interface to about $-4 \%$ at the bottom of the holes. Anderson and Schneidermann
(1973) noted an unusually steep $\delta \mathrm{O}^{18}$ gradient $\left(-4^{0} \%\right.$ to $+7 \%$ ) in Upper Cretaceous limestones from near the basement of Sites 146 and 153. However, no decrease of the $\mathrm{O}^{18}$ content with depth was observed in the overlying unconsolidated oozes.

It is obvious that the limestones with $\delta \mathrm{O}^{18}$ values of up to $-7 \%$ ore inconsistent with lithification at the sea floor, because the lowest observed values correspond to an equilibrium water temperature of about $50^{\circ} \mathrm{C}$. This high reading rules out bottom water as the equilibrating fluid. According to Anderson and Schneidermann (1973), the strongly negative isotope shift is a result of cementation and recrystallization of limestones during periods of abnormally high heat flow related to volcanic activity, an interpretation which has been questioned by Coplen and Schlanger (1973). From the absence of compaction features and dissolution welding, Anderson and Schneidermann (1973) conclude that cementation occurred during early diagenesis and in the shallow burial realm.

\section{Isotope Data from Sites 305 and 306}

Calcareous nannoplankton and planktonic foraminifera initially have similar $\mathrm{O}^{18} / \mathrm{O}^{16}$ ratios because they both live in the near-surface waters. However, during diagenesis nannofossils act as receptors of calcite cement whereas planktonic foraminifera are donors of carbonate. Assuming that the $\mathrm{O}^{18} / \mathrm{O}^{16}$ ratio of the preserved planktonic foraminifera has not been changed (which is incorrect in the deeper parts of the holes), it is possible to estimate the amount of isotopic reequilibration of nannofossils by comparing their isotopic ratio with that of the foraminifera. Another approach is to compare oxygen isotope ratios in the solid phase and the interstitial fluids (Lawrence, 1973).

The isotopic composition of planktonic foraminifera from Site 305 has not yet been measured. However, we can compare the oxygen isotope values of Figure 3 with the oxygen isotope profiles from Site 167 (Magellan Rise) and Site 47 (Shatsky Rise). The values from the nannofossils are the same in the Plio-Pleistocene or only slightly higher in the early Tertiary than those from planktonic foraminifera, but in the mid-Tertiary the nannofossils give values which are consistently higher by about $1 \%$. 
Textural observations indicate that these higher values are due to overgrowth cement precipitated preferentially on the nannofossils during early diagenesis. The lack of overgrowth cement in the overlying PlioPleistocene oozes explains the identical oxygen isotope compositions of nannofossils and planktonic foraminifera from this unit. The textural data and strontium values both indicate that below 50 meters the ratio of overgrowth cement to primary biogenic calcite increases with depth. This trend is inconsistent with cementation at the sea floor. In addition, the sediments have none of the textural characteristics of submarine lithified crusts (Milliman, 1974), nor have they been exposed for extended periods at the sea floor. They apparently accumulated continuously and at normal rates from the Early Cretaceous unt.. the Paleocene (Figure 3).

Our data are consistent with progressive lithification under a normal geothermal gradient. The sediments lithify by dissolution of thermodynamically instable biogenic particles and precipitation of overgrowth cement on the more stable ones. Lithification starts in the lower shallow burial realm (early diagenesis) and continues, with increasing overburden and temperature, in the deeper burial environment (late diagenesis). This is confirmed by the trend of strontium values which matches the oxygen isotope profile (Figure 3). A positive correlation is found between these parameters (Figure 5). The logarithm of $\mathrm{mSr}^{2+} / \mathrm{mCa}^{2+}$ is related to $\delta \mathrm{O}^{18}$ with a correlation coefficient of 0.92 . If we exclude the values from Site 306 the correlation coefficient is still 0.91 . This cor- relation has a geologic meaning and is not merely the result of the independent correlation of each parameter with depth.

Dissolution and reprecipitation involve a considerable ion exchange as well as an isotopic exchange between solids and interstitial waters (Lawrence, 1973). Because we do not know the amount of isotope fractionation nor the isotopic composition of the pore waters, it is impossible to quantitatively estimate the isotopic composition of the cement.

The difference in the isotopic composition of benthonic and planktonic foraminifera from the same samples (Douglas and Savin, this volume) suggests that they did not re-equilibrate with the pore fluids. Thus, there is only partial isotopic adjustment in pelagic carbonates, namely in the reprecipitated calcite cement preferentially deposited on nannofossils. Therefore, the $\delta \mathrm{O}^{18}$ value of nannofossil calcite is an average of the isotopic composition of the original nannofossil and the overgrowth cement. Because geothermal temperature increases downhole, the isotopic composition of the calcite cement should approach the primary oxygen isotope composition of the nannofossils. In addition, the tests of planktonic foraminifera recrystallize and accrete calcite cement in the deeper depths of burial, which brings them isotopically closer to the overgrown nannofossils.

Although lithification of carbonate oozes may occur during periods of nondeposition, our data from Sites 305 and 306 indicate that this is a minor process. There-

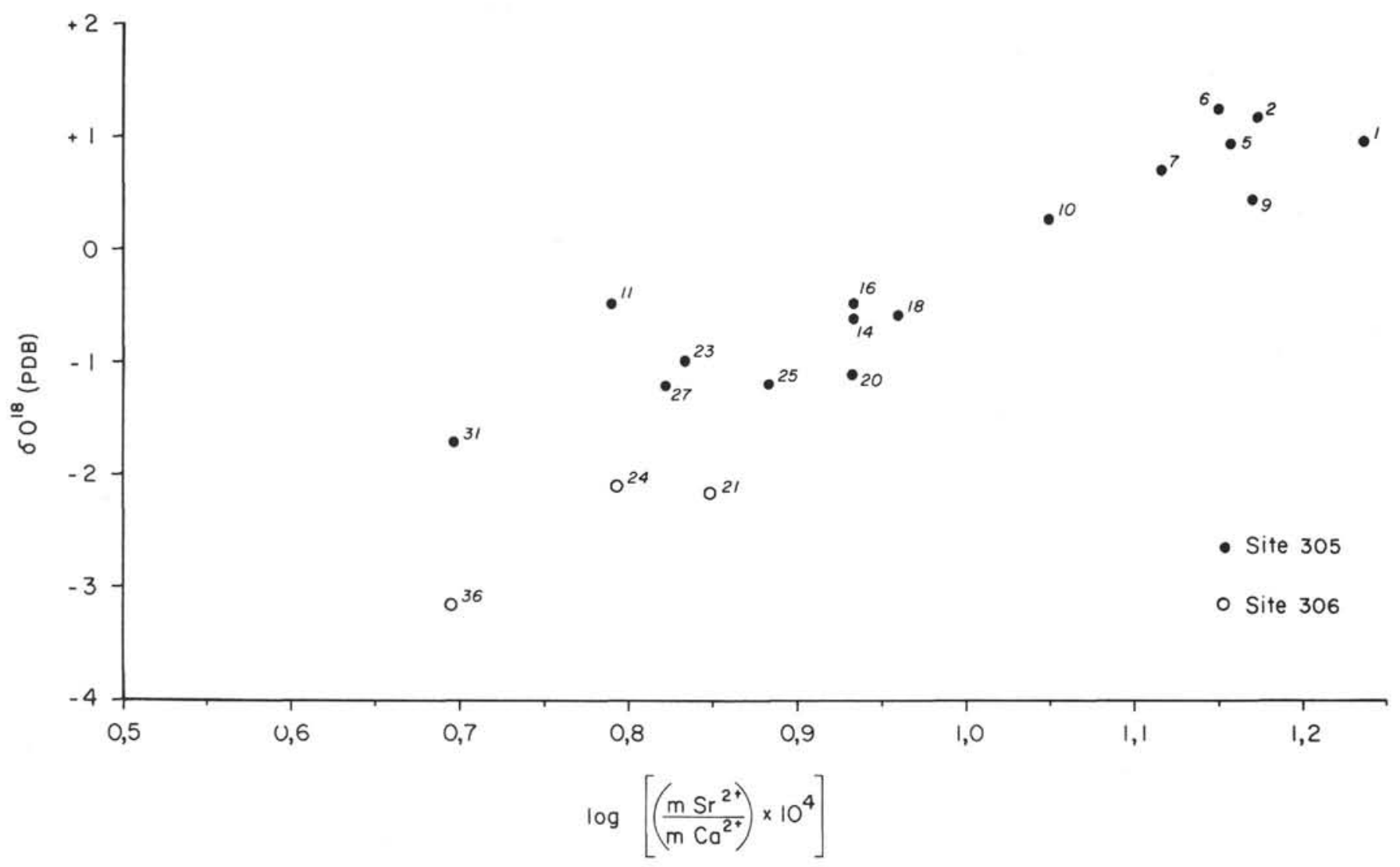

Figure 5. Plot of $\delta \mathrm{O}^{18}$ (nannofossils) against $\log \left(\mathrm{mSr}^{2+} / \mathrm{Ca}^{2+}\right)$ of the bulk sediment. 
fore, layers such as the Braarudosphaera chalk (Wise and Hsü, 1971) are atypical. Our data show a systematic increase in cementation with depth which is accompanied by an equally systematic decrease of $\delta \mathrm{O}^{18}$. The oxygen "shift" in the middle Tertiary, however, reflects mainly rapid cooling of the water masses and less the isotopically re-equilibrated calcite overgrowth effect of diagenesis. Because the $\mathrm{C}^{13} / \mathrm{C}^{12}$ ratios in shells and in the water in which they live show only a very small temperature-dependent difference, we believe that the observed trend reversal at Site 305 reflects an isotopic change in the water mass rather than diagenetic alteration. Increasing $\mathrm{C}^{13}$ concentrations from the Pleistocene to Eocene were also noted at Site 147, drilled in the Cariaco Trench off Venezuela. These high concentrations are attributed to precipitation of small amounts of authigenic calcite cement, assuming derivation of the $\mathrm{C}^{12}$ from organic matter (Lawrence, 1973).

\section{EVOLUTION OF TEXTURES}

The texture of ancient sedimentary rocks is composed of a depositional and a diagenetic component. The depositional texture of a freshly deposited sediment is a function of composition, particle size, sorting, and packing of the grains. These properties are altered by diagenetic processes which include dissolution of particles, compaction, and deposition of cement.

Dissolution of planktonic foraminifera and calcareous nannoplankton starts as they settle through the water column and continues after burial. Apparently dissolution of planktonic foraminifera is minor during settling as compared to their dissolution rate on the sea floor (Adelseck and Berger, 1974). Although the mass of nannofossils settles as aggregates in fecal pellets produced by planktonic predators and not individually, the settling time of these pellets is still an order of magnitude less than that of foraminiferal tests (Smayda, 1971; Honjo, 1974). Nannofossils are therefore more affected by dissolution during their transit from the photic layer to the deep-sea floor.

The evolution of the diagenetic texture with increasing overburden and age is governed by in situ progressive dissolution of the more unstable components and reprecipitation of the carbonate as overgrowth cement on the more robust constituents. Adelseck et al. (1973) have experimentally demonstrated that dissolution and reprecipitation take place in the same sample. Dissolution and overgrowth features were observed in many samples from Sites 305 and 306, even on the same nannofossil (Plate 3, Figure 13; Plate 4, Figures 7, 10, etc). This does not prove, however, the simultaneity of both processes, because the dissolution feature might be a preburial phenomenon. A time relationship can be established if partly dissolved elements have been overgrown (Plate 4, Figure 7; Matter, 1974, pl. 7, fig. 6), or if overgrowths have been dissolved. Only in the latter case can we be sure that both processes have taken place in the diagenetic realm.

Several authors have shown that overgrowth cement is preferentially deposited on discoasters, braarudosphaerid plates, and on the proximal side of the distal shield of the more dissolution-resistant coccoliths. It appears that accretion of overgrowth cement is dependent on (1) crystal size, the larger seed crystals have less free energy and grow at the expense of smaller ones whose free energy is greater (Bathurst, 1971; Berner, 1971; (2) crystal shape (Neugebauer, 1974) and; (3) the orientation of the crystals' c-axis. In the case of placoliths this occurs if each element of the distal and proximal shield is part of the same single crystal. Apparently, overgrowth is species selective and is open to a ranking analogous to the selective dissolution ranking (Berger, 1968; Parker, 1967; McIntyre and McIntyre, 1971; Bukry, 1971; and Schneidermann, 1973).

Black $(1963,1972)$ has published excellent studies on the crystal structure of calcareous nannofossils. The discoasters, braarudosphaerids, and most coccoliths are composed of rhombohedral crystals. The trigonal c-axis is oriented parallel to the line of vision in the microscope when viewing discoasters and the distal shields of some coccoliths, such as $E$. ovalis, $C$. leptopora, etc. It has been shown that diagenetic growth of crinoid ossicles by syntaxial overgrowth is fastest in the direction of the caxis and conversely dissolution is slowest on the faces perpendicular to the c-axis (Bain, 1940, cited in Adelseck et al., 1973). The faster growth rate, parallel to the c-axis, of the rhomb-shaped coccoliths' elements explains why the intershield space of placoliths is bridged early during coccolith diagenesis.

\section{PROGRESSION OF DIAGENESIS}

The transitions from ooze to chalk to limestone are gradual and, although lithification increases with depth and age, inversions occur (i.e., less lithified layers may be found below harder ones). According to Schlanger and Douglas (1974) this is a function of the diagenetic potential of the sediment: beds with a higher potential will lithify earlier than those with a lower one. An example is the Upper Cretaceous to Paleocene sequence at Site 305 where oozes alternate with chalk layers. The transitions appear to be gradual at Sites 305 and 306, yet several distinct diagenetic zones can be distinguished which correspond more or less with the lithologic units.

\section{Zone 1}

Soft oozes $(0$ to $50 \mathrm{~m})$ are characterized by abundant nannofossils which show few signs of dissolution and overgrowth and a strongly dissolved temperate planktonic foraminiferal fauna with low planktonic to benthonic ratios. The concentration of $\mathrm{Ca}^{2+}$ in the interstitial water is identical to that of average seawater, which suggests that dissolution of the foraminifera took place during the preburial stage. Gravitational compaction is the dominant process in this zone. This process leads to expulsion of pore waters and to a porosity reduction of $10 \%$.

\section{Zone 2}

Zone 2 is composed of stiff, pure carbonate oozes ( 50 to $140 \mathrm{~m})$. In the upper two-thirds of this zone, bracketed by unconformities (Figure 2), marked changes in all the measured parameters are noticed. The calcareous nannoplankton assemblage shows a fair proportion of fragmented and partly dissolved specimens. 
Most delicate central structures are missing and the proximal shields show signs of strong dissolution. Poorly preserved proximal shields of the dissolution-resistant C. pelagicus occur together with well-preserved ones.

Thick overgrowths of calcite cement are found on discoasters, sphenoliths, and elements which bridge the intershield space of Prinsiaceae. Considerable dissolution of planktonic foraminifera is also indicated by the low planktonic to benthonic ratios. These textural changes are accompanied by a large decrease of strontium and magnesium in the bulk sample and large shifts to lower $\delta \mathrm{O}^{18}$ and higher $\delta \mathrm{C}^{13}$ values. The porosity decreases by another $10 \%$ in this interval to $50 \%$.

Benthonic foraminifera indicate that bottom temperatures cooled during the mid-Tertiary, increasing the dissolution rate of skeletal particles on the sea floor. Particularly the planktonic foraminiferal species richer in magnesium, which are also the shallower dwelling ("warmer") ones, were preferentially dissolved. This caused a reduction of the magnesium content of the accumulating sediment and also can explain the low accumulation rate of $2 \mathrm{~m} / \mathrm{m}$.y.

After burial, dissolution of biogenic particles, especially of planktonic foraminifera, delicate parts of coccoliths, and tiny supersoluble grains continued, and strontium-depleted calcite cement was precipitated on nannofossils. This cement, precipitated in equilibrium with the pore waters, has a higher $\delta \mathrm{O}^{18}$ concentration than the biogenic particles. The post-Paleocene $\delta \mathrm{C}^{13}$ decrease is probably attributed to a different water mass with much lower temperatures as indicated by the large shift in the oxygen isotope composition of the calcareous nannoplankton.

Zones 1 and 2 represent the shallow burial realm of Schlanger and Douglas (1974).

\section{Zone 3}

Below the lower Eocene unconformity the stiff oozes described above gradually pass into Late Cretaceous chalks and then into radiolarian limestones and porcellanites. As indicated by the high planktonic to benthonic ratios, dissolution of planktonic foraminifera was less than in the post-Paleocene. However, dissolution of calcareous nannofossils during the two periods was similar. Dissolution of nannofossils is severe below 250 meters down to the bottom of the hole. In the porcellanites and lowermost chalks only the most robust nannofossils, such as Watznaueria and some benthonic foraminifera, are preserved. In the absence of discoasters and sphenoliths, calcite is precipitated onto zygoliths' walls and micritic grains. Watznaueria and other placoliths have welded shields, and their central structures are masked by overgrowth cement.

Many coccoliths and micritic grains are replaced by silica in the radiolarian limestones and porcellanites. Silicification enhanced lithification and the reduction of porosity. The nannofossil chalk below the porcellanites has retained more pore space and has a better preserved low-diversity flora than do the silicified sediments. Many particles have accreted large amounts of syntaxial calcite cement which frequently envelops parts of or entire coccoliths and occludes much of the pore space and fills chambers of foraminifera. Authigenic dolomite takes up most or all of the magnesium which is released by dissolution of biogenic calcite. However, some magnesium is eventually incorporated into calcite cement.

Increasing lithification with depth is achieved by dissolution of planktonic foraminifera and all but the most robust calcareous nannofossils and the precipitation of strontium-poor cement onto the remaining calcareous particles. Progressive lithification and stabilization of pelagic carbonates starts during early diagenesis in the shallow burial realm and continues in the deeper burial environment with increased overburden and age (late diagenesis). This is clearly indicated by the decrease of strontium with increasing lithification.

\section{SOME QUANTITATIVE ASPECTS OF LITHIFICATION OF PELAGIC CARBONATES FROM SITES 305 AND 306}

To fully understand the mechanisms of lithification, it is important to get a quantitative estimate of how much of the original constituents have been dissolved and how much cement has been reprecipitated. If benthonic foraminifera comprise about $0.02 \%$ of a well-preserved tropical assemblage and they are considered insoluble, we can calculate the carbonate loss caused by dissolution of planktonic foraminifera using schemes proposed by Berger (1971) and Douglas (1973a, b). The average foraminiferal carbonate loss is $94 \%$ in the 52 to 100 meter interval at Site 305 . But if a large proportion of the planktonic foraminifera was dissolved at the sea floor, the porosity reduction caused by dissolution of planktonic foraminifera, as advocated by Schlanger et al. (1973) and Schlanger and Douglas (1974), can only be accounted for if sea-floor dissolution is ruled out. Because the amount of nannofossil carbonate loss is almost impossible to determine, the total carbonate loss due to dissolution cannot be estimated by visual examination of the samples.

However, investigation of the oxygen and carbon isotopes (Lawrence, 1973) and the strontium abundance in the sediments and pore waters may provide the key to quantification of the diagenetic processes. We shall only consider strontium because we have no isotope data on the interstitial fluids. Both strontium and magnesium concentrations in recent deep-sea carbonate oozes are much lower than in shallow-water carbonate sediments. However, from the sparse published data (Manheim and Sayles, 1971) it is suspected that deep-sea carbonates, which obviously have been in continuous contact with pore fluids derived from seawater, are being depleted of strontium with progressive diagenesis. It was suggested by Kinsman (1969) that the strontium concentrations of diagenetically altered limestones could be used to follow the diagenetic pathways. We must know the strontium content of the unaltered sediment and of the interstitial water, as well as the strontium partition coefficient for calcium in order to estimate the amount of calcite cement. The accuracy of these estimates depends largely on how close the experimentally determined partition coefficient of 0.05 (Katz et al., 1972) reflects the true coefficient. If we simplify the calculations by assuming the total cement in a sample was precipitated in 
equilibrium with the same pore water found today in this sample, the carbonate at 53 meters would consist of $87 \%$ biogenic calcite and $13 \%$ cement containing 510 ppm strontium. The cement would amount to $64 \%$ of the solid carbonate phase at 100 meters, and to $76 \%$ at 240 meters (Table 3). The low strontium concentration of the carbonates at the bottom of the holes ( 350 to 550 $\mathrm{ppm}$ ) can only be reached via the dissolutionreprecipitation process provided the strontium concentration of the pore waters is low and decreases with depth. This would be the case if a high amount of previously precipitated low strontium cement is dissolved. Our studies of textures show that this is the case.

If the sediments are depleted of strontium during shallow and deep burial, and not during dissolution at the sea floor, we must have a mechanism by which the excess strontium is moved out of the sediment column. The ratio of $\mathrm{mSr}^{2+}$ to $\mathrm{mCa}^{2+}$ would otherwise increase, because of the dissolution of the more soluble magnesium-bearing biogenic particles, to values which would be much higher than the values observed now in the pore waters (Table 3 ).

The total quantity of pore water expelled by compaction has only carried back to the sea a small amount of the strontium which is missing in the sediments. The only effective way to remove the dissolved strontium is by diffusion. This seems to be an unsatisfactory explanation because there is barely any concentration gradient. The problem could be solved by assuming (a) that the $\mathrm{Sr}^{2+}$ which was dissolved from the carbonates was incorporated into another solid phase, e.g., clay minerals in which case the bulk composition of the samples should remain constant or (b) that the studied sediments do not reflect a steady-state process.

Manheim and Sayles (1971) reported increased strontium concentrations with depth, reaching values of 40 to $119 \mathrm{ppm}$, from several holes. Using the partition coefficient of 0.05 and their calcium data, the cements precipitated from such solutions should contain between 1500 to $2200 \mathrm{ppm}$. Certainly deposition of these cements would not decrease the $\mathrm{Sr}^{2+}$ concentration of pelagic carbonates during lithification.

Thus, strontium is certainly an excellent quantitative measure of the diagenetic grade of pelagic carbonates, and it is a valuable tool for estimating the amount of precipitated cement. However, several critical aspects, such as the mode of removal of strontium from the sediment column, have to be solved before we fully comprehend the lithification process.

TABLE 3

Estimates of the Amount of Biogenic Particles and Calcite Cement, Calculated on the Basis of Pore-water Composition and a Primary Concentration of $1350 \mathrm{ppm}$ for Strontium in the Unaltered Sediment, $\mathrm{Sr}=0.05$

\begin{tabular}{|c|c|c|c|}
\hline $\begin{array}{l}\text { Depth } \\
\text { (m) }\end{array}$ & $\begin{array}{c}\text { Composition o } \\
\text { Biogenic }(\%)\end{array}$ & $\begin{array}{l}\text { bulk carbonate } \\
\text { Cement }(\%)\end{array}$ & $\begin{array}{l}\mathrm{Sr}^{2+} \text { in ce- } \\
\text { ment (ppm) }\end{array}$ \\
\hline 53 & 87 & 13 & 510 \\
\hline 100 & 37 & 64 & 480 \\
\hline 240 & 24 & 76 & 440 \\
\hline
\end{tabular}

\section{ACKNOWLEDGMENTS}

The senior author would like to thank the scientific and technical teams aboard Glomar Challenger for the excellent cooperation during the 2 -month cruise. The study has benefited from discussions with E. Jäger (Bern), D. Imboden, T. Li, and S. Emerson (Zürich). The cooperation and helpful assistance of F. Zweili with the SEM and of A. Egger and B. Wieland with atomic absorption and X-ray fluorescence analyses are kindly acknowledged. Mrs. Ivy Yeh and Miss Diane Eskenasy assisted in the isotopic analyses. The illustrations were prepared by U. Ernst, U. Furrer, H. Ischi, and A. Breitschmid and their help is greatly appreciated. Miss S. Sahli typed the manuscript. R. Herb (Bern) and K.J. Hsü (Zürich) critically reviewed and improved the manuscript. Finally, we would like to express our gratitude to J.V. Gardner of the Deep Sea Drilling Project for editing this article. The isotopic and foraminiferal analyses were supported by NSF Grants GA16827 and GA31622.

\section{REFERENCES}

Adelseck, C.G., Geehan, G.W., and Roth, P.H., 1973. Experimental evidence for the selective dissolution and overgrowth of calcareous nannofossils during diagenesis: Geol. Soc. Am. Bull., v. 84, p. 2755-2762.

Adelseck, C.G. and Berger, W.H., 1974. Dissolution of foraminifera from the sediment-seawater interface: Symp. "Marine plankton and sediments" and Plankt. Conf. 3rd, Kiel, p. 5.

Anderson, T.F. and Schneidermann, N., 1973. Stable isotope relationships in pelagic limestones from the Central Caribbean: Leg 15, Deep Sea Drilling Project. In Edgar, N.T., Saunders, J.B., et al., Initial Reports of the Deep Sea Drilling Project, Volume 15: Washington (U.S. Government Printing Office), p. 795-803.

Bathurst, R.G.C., 1971. Carbonate sediments and their diagenesis: Amsterdam (Elsevier).

Berger, W.H., 1968. Planktonic foraminifera: selective solution and paleoclimatic interpretation: Deep-Sea Res., v. 15, p. 31-43.

, 1971. Sedimentation of planktonic foraminifera: Marine Geol., v. 11 , p. 325-358.

Berger, W.H. and von Rad, U., 1972. Cretaceous and Cenozoic sediments from the Atlantic Ocean. In Hayes, D.E., Pimm, A.C. et al., Initial Reports of the Deep Sea Drilling Project, Volume 14: Washington (U.S. Government Printing Office), p. 787-954.

Berner, R.A., 1971. Principles of chemical sedimentology: New York (McGraw Hill).

Black, M., 1963. The fine structure of the mineral parts of Coccolithophoridae: Linnean Soc. London, Proc., v. 174, p. 41-46.

1972. Crystal development in Discoasteraceae and Braarudosphaeraceae (planktonic algae): Paleontology, v. 15 , p. 476-489.

Broecker, W.S., 1974. Chemical oceanography: New York (Harcourt Brace Jovanovich, Inc.).

Bukry, D., 1971. Cenozoic calcareous nannofossils from the Pacific Ocean: San Diego Soc. Nat. Hist. Trans, v. 16, p. 303-328.

Cook, F.M. and Cook, H.E., 1972. Physical properties synthesis. In Hayes, J.D. et al., Initial Reports of the Deep Sea Drilling Project, Volume 9: Washington (U.S. Government Printing Office), p. 645-646.

Coplen, T.B. and Schlanger, S.O., 1973. Oxygen and carbon isotope studies of carbonate sediments from Site 167, Magellan Rise, Leg 17. In Winterer, E.L., Ewing, J.I. et al., Initial Reports of the Deep Sea Drilling Project, Volume 
17: Washington (U.S. Government Printing Office), p. 505 509.

Davies, T.A. and Supko, P.R., 1973. Oceanic sediments and their diagenesis: some examples from deep-sea drilling: J. Sediment. Petrol., v. 43, p. 381-390.

Douglas, R.G., 1973a. Benthonic foraminiferal biostratigraphy in the Central North Pacific, Leg 17, Deep Sea Drilling Project. In Winterer, E. L., Ewing, J.I., et al., Initial Reports of the Deep Sea Drilling Project, Volume 17: Washington (U.S. Government Printing Office), p. 607-671.

Douglas, R.G., 1973b. Planktonic foraminiferal biostratigraphy in the Central North Pacific Ocean. In Winterer, E.L., Ewing, J.I. et al., Initial Reports of the Deep Sea Drilling Project, Volume 17: Washington (U.S. Government Printing Office), p. 673-694.

Douglas, R.G. and Savin, S.M., 1971. Isotopic analyses of planktonic foraminifera from the Cenozoic of the Northwest Pacific, Leg 6. In Fischer, A.G. et al., Initial Reports of the Deep Sea Drilling Project, Volume 6: Washington (U.S. Government Printing Office), p. 1123-1127.

Goldsmith, J.R., Graf, D.L., and Heard, H.C., 1961. Lattice constants of the calcium-magnesium carbonates: Am. Mineralogist, v. 46 , p. $453-457$.

Honjo, S., 1969. Study of the fine grained carbonate matrix: sedimentation and diagenesis of "micrite." In Matsumoto, T. (Ed.), Litho- and bio-facies of carbonate sedimentary rocks-a symposium: Pal. Soc. Japan, Spec. Papers 14, p. $67-82$.

1974. Sedimentation of coccoliths in deep-sea, procedure of replication from the surface to the sediment assemblage (abst). Symposium "Marine plankton and sediments" and Plankt. Conf. 3rd, Kiel.

Katz, A., Sass, E., Starinsky, A., and Holland, H.D., 1972. Strontium behavior in the aragonite-calcite transformation: an experimental study at $40-98^{\circ} \mathrm{C}$. Geochim. Cosmochim. Acta, v. 36, p. 481-496.

Kennedy, W.J. and Garrison, R.E., in press. Morphology and genesis of nodular chalks and hardgrounds in the Upper Cretaceous of Southern England: Sedimentology, v. 22.

Kinsman, D.J.J., 1969. Interpretation of $\mathrm{Sr}^{2+}$ concentrations in carbonate minerals and rocks: J. Sediment. Petrol., v. 39, p. $486-508$.

Lawrence, J.R., 1973. Interstitial water studies, Leg 15Stable oxygen and carbon isotope variations in water, carbonates, and silicates from the Venezuela Basin (Site 149) and the Aves Rise (Site 148). In Heezen, B.C., MacGregor, Ian D., et al., Initial Reports of the Deep Sea Drilling Program, Volume 20: Washington (U.S. Government Printing Office), p. 891-899.

Lloyd, R.M. and Hsil, K.J., 1972. Stable isotope investigations of sediments from the DSDP III cruise to South Atlantic: Sedimentology, v. 19, p. 45-58.

Manheim, F.T. and Sayles, F.L., 1971. Interstitial water studies on small core samples, Deep Sea Drilling Project, Leg 8. In Tracey, J.I., Jr., et al., Initial Reports of the Deep Sea Drilling Project, Volume 8: Washington (U.S. Government Printing Office), p. 857-869.

Matter, A. 1974. Burial diagenesis of pelitic and carbonate deep-sea sediments from the Arabian Sea. In Whitmarsh, R.B., Weser, O.E., and Ross, D.A., et al., Initial Reports of the Deep Sea Drilling Project, Volume 23: Washington (U.S. Government Printing Office), p. 421-469.

McIntyre, A. and McIntyre, R., 1971. Coccolith concentrations and differential solution in oceanic sediments. In Funnel, B.M. and Riedel, W.R. (Eds.), The micropaleontology of oceans: Cambridge (Cambridge University Press).

Milliman, J.D., 1966. Submarine lithification of carbonate sediments: Science, v. 153, p. 994-997.
1971. Examples of submarine lithification. In Bricker, O.P. (Ed.), Carbonate cements: The Johns Hopkins Univ. Studies in Geol., no. 19, p. 95-102.

1974. Marine carbonates, Part 1 of Recent sedimentary carbonates. In Milliman, J.D., Muller, G., and Förstner, U., (Eds.), Berlin, New York (Springer).

Neugebauer, J., 1973. The diagenetic problem of chalk: N. Jb. Geol. Paläont. Abh., v. 143, p. 223-245.

1974. Some aspects of cementation in chalk. In Hsü, K.J. and Jenkyns, H.C. (Eds.), Pelagic sediments: on land and under the sea: Spec. Publ. 1, Int. Assoc. Sedimentologists.

Okada, H. and Honjo, S., 1970. Coccolithophoridae distribution in southwest Pacific: Pacific Geol., v. 2, p. 11-21.

Parker, F.L., 1967. Distribution of planktonic foraminifera in Recent deep-sea sediments. In Funnell, B.M. and Riedel, W.R. (Eds.), The micropaleontology of the Oceans: Cambridge (Cambridge University Press), p. 289-307.

Perch-Nielsen, K., 1971. Elektronenmikroskopische Untersuchungen an Coccolithen und verwandten Formen aus dem Eozän von Dänemark: Kongelige Danske Videnskabernes Selskab, Biologiske Skrifter, v. 18 (3).

1972. Remarks on late Cretaceous to Pleistocene coccoliths from the North Atlantic. In Langhton, A.S., Berggren, W.A., et al., Initial Reports of the Deep Sea Drilling Project, Volume 12: Washington (U.S. Government Printing Office), p. 1003-1070.

Pray, L.C., 1960. Compaction in calcilutites: Geol. Soc. Am. Bull., v. 71, p. 1946 (abstract).

Savin, S.M. and Douglas, R.G., 1973. Stable isotope and magnesium geochemistry of Recent planktonic foraminifera from the South Pacific: Geol. Soc. Am. Bull., v. 84, p. $2327-$ 2342.

Sayles, F.L., Manheim, F.T., and Waterman, L.S., 1974. Interstitial water studies on small core samples, Leg 15. In Heezan, B.C., MacGregor, I.D., et al., Initial Reports of the Deep Sea Drilling Project, Volume 20: Washington (U.S. Government Printing Office), p. 783-804.

Schlanger, S.O. and Douglas, R.G., 1974. The pelagic oozechalk-limestone transition and its implications for marine stratigraphy. In Hsu, K.J. and Jenkyns, H.C. (Eds.), Pelagic sediments: on land and under the sea: Spec. Publ. 1, Int. Assoc. Sedimentologists, p. 403-434.

Schlanger, S.O., Douglas, R.G., Lancelot, Y., Moore, T.C., Jr., and Roth, P.H., 1973. Fossil preservation and diagenesis of pelagic carbonates from the Magellan Rise, Central North Pacific Ocean. In Winterer, E.L., Ewing, J.L. et al., Initial Reports of the Deep Sea Drilling Project, Volume 17: Washington (U.S. Government Printing Office), p. 407-427.

Schneidermann, N., 1973. Deposition of coccoliths in the compensation zone of the Atlantic Ocean. In Smith, L.A., and Hardenbol, J. (Eds.), Proc. Symp. Calcareous nannofossils, Gulf Coast Section Soc. Econ. Paleont. Min: Houston, Texas, p. 140-151.

Scholle, P., 1974. Diagenesis of Upper Cretaceous chalks from England, Northern Ireland, and the North Sea. In Hsu, K.J. and Jenkyns, H.C. (Eds.): Pelagic sediments: on land and under the sea. Spec. Publ. 1, Int. Assoc. Sedimentologists, p. 97-103.

Smayda, T.J., 1971. Normal and accelerated sinking of phytoplankton in the sea: Marine Geol., v. 11, p. 105-122.

Tracey, J.I. Jr, et al., 1971. Initial Reports of the Deep Sea Drilling Project, Volume 8: Washington (U.S. Government Printing Office).

Wise, S.W., 1973. Calcareous nannofossils from cores recovered during Leg 18, Deep Sea Drilling Project: Biostratigraphy and observations of diagenesis. In Kulm, L.D., 
von Huene, R., et al., Initial Reports of the Deep Sea Drilling Project, Volume 18: Washington (U.S. Government Printing Office), p. 569-615.
Wise, S.W. and Hsu, K.J., 1971. Genesis and lithification of a deep sea chalk: Ecolog. Geol. Helv., v. 64, p. 73-278. 


\section{PLATE 1}

Microfacies and texture of Site 305 carbonates. All figures are scanning electron photomicrographs of fracture surfaces.

Figure 1 Soft siliceous foram-rich nanno ooze from Unit 1 with many broken shields of Coccolithus leptoporus (Murray and Blackman) (arrows), abundant micritic carbonate particles formed by disaggregation of nannofossils and moderately preserved diatoms. $305-5-3,50 \mathrm{~cm}(39.0 \mathrm{~m})$.

Figures 2, 3 Soft foram nanno ooze from Unit 2. Figure 2 shows many isolated distal shields with dissolved central structures of Prinsiaceae and heavy overgrowth on discoasters. In Figure 3 dissolution has affected discoaster (center left) prior to overgrowth. Pressure dissolution is recognizable between coccoliths (arrow). Notice much denser packing in Figure 3 than in Figure 2.

2. $305-10-3,130 \mathrm{~cm}(86.3 \mathrm{~m})$.

3. $305-13-4,90 \mathrm{~cm}(115.9 \mathrm{~m})$.

Figure $4 \quad$ Foram-rich nanno chalk from upper part of Unit 3. Abundant small carbonate particles with heavy overgrowths on the calcareous nannofossils which show euhedral crystal faces, and a remnant of a foraminiferal wall (arrow) are seen. 305-23-5, 120 $\mathrm{cm}(212.2 \mathrm{~m})$.

Figure $5 \quad$ Silicified radiolarian nannofossil limestone from basal part of Unit 3 showing few dissolution-resistant coccoliths or their replicas or molds in a dense silicified groundmass. Notice larger euhedral carbonate crystals. $305-47-1,128 \mathrm{~cm}$ $(439.28 \mathrm{~m})$.

Figure 6 Weakly silicified radiolarian nanno limestone from upper part of Unit 4 showing many tightly packed and overgrown dissolution-resistant Watznaueria barnesae (Black) and small carbonate particles. $305-64-1,100 \mathrm{~cm}(599.0 \mathrm{~m}), \times 3600$. 
PLATE 1
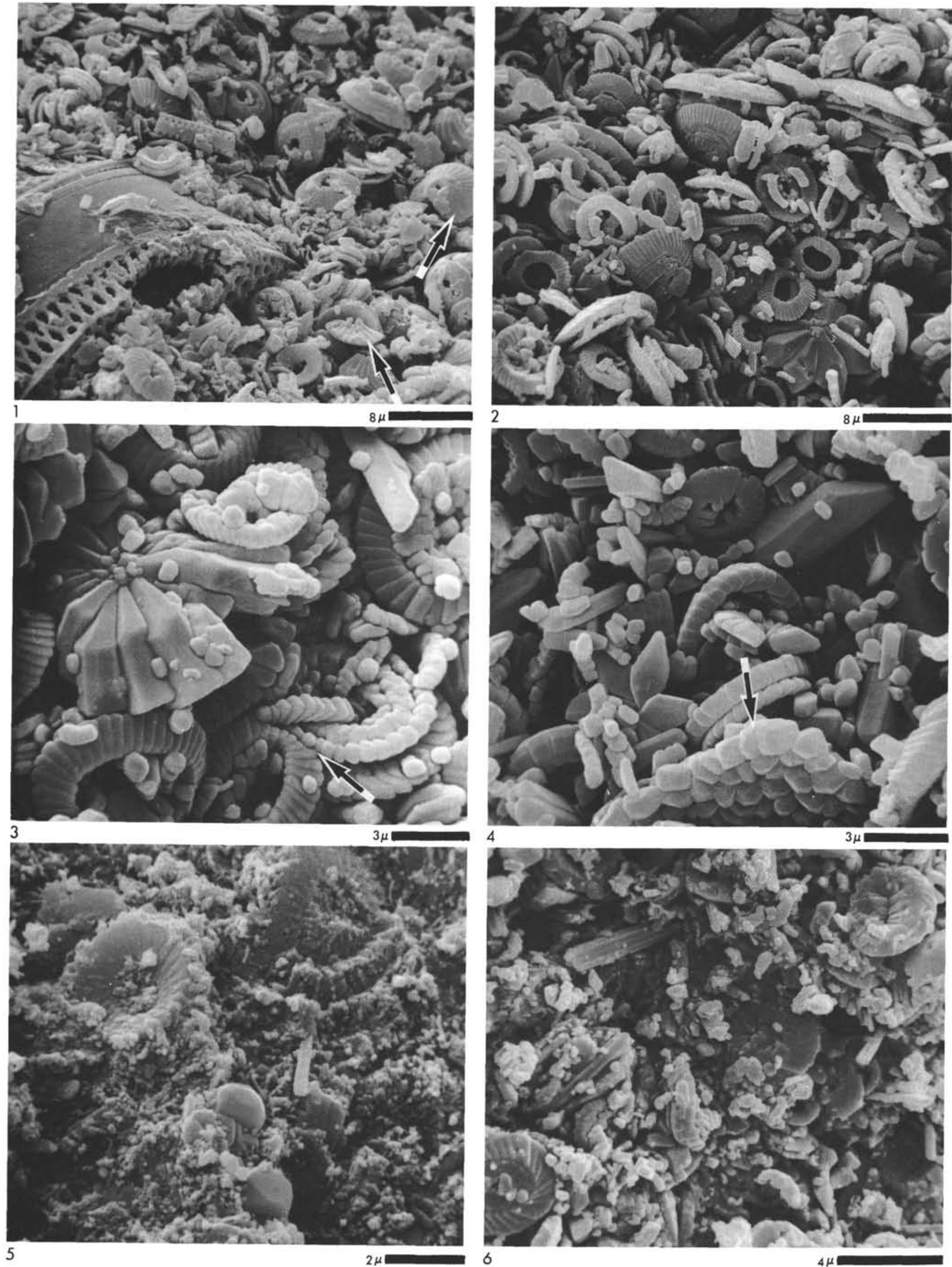


\section{PLATE 2}

Microfacies and texture of Site 306 carbonates. Figures 1 to 5 are scanning electron photomicrographs of fracture surfaces, Figure 6 is a photomicrograph.

Figures 1, 2 Calcareous porcellanite. Heavily overgrown coccoliths or their molds are seen in a dense silicified groundmass in Figure 1. The acid-treated specimen in Figure 2 shows that most of the carbonate particles except the sturdiest coccoliths have been replaced by silica. Compare also Plate 7. 306-8-1, $38 \mathrm{~cm}(113.38 \mathrm{~m})$.

Figures 3,4 Chalk samples from Unit 5 showing dissolution and overgrowth features on coccoliths and disaggregated coccoliths. Notice larger calcite crystals which have grown by deposition of overgrowth cement on coccolith fragments and which now occlude some of the pore space (Figure 4).

3. $306-21-1,62 \mathrm{~cm}(281.62 \mathrm{~m})$.

4. $306-26$, CC $(337.0 \mathrm{~m})$.

Figure 5 Twinned dolomite crystals from 306-26, CC (337.0 $\mathrm{m})$. Average composition of many crystals is $\mathrm{Ca}_{54} \mathrm{Mg}_{46}\left(\mathrm{CO}_{3}\right)_{2}$. For detail of crystal surface see Plate 7, Figure 11.

Figure 6 Limestone with Lenticulina sp. showing recrystallized walls and chambers filled with calcite spar and bipyramidal prisms of authigenic baryte. 305$64-1,100 \mathrm{~cm}(559.0 \mathrm{~m})$. 


\section{PLATE 2}
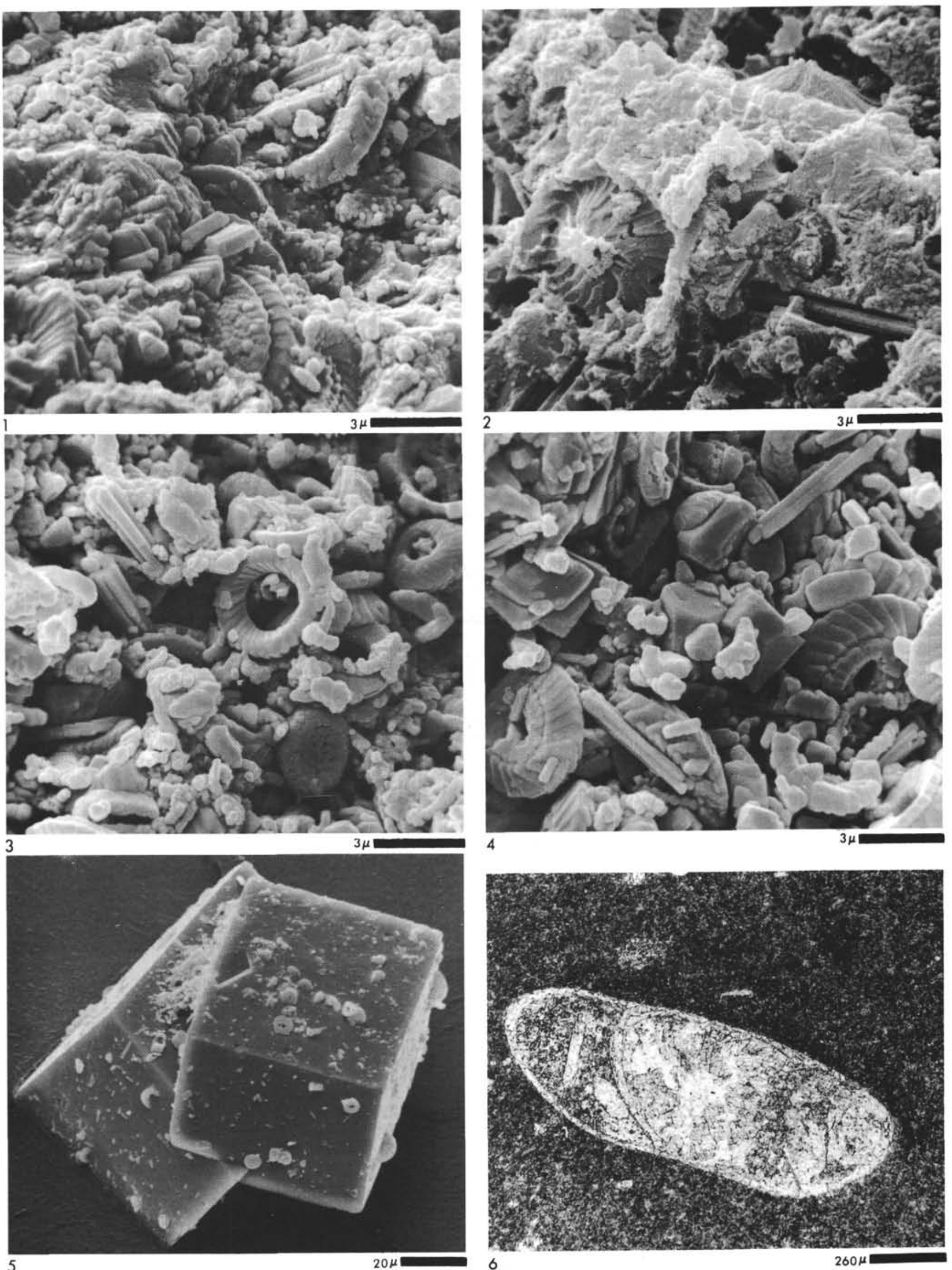


\section{PLATE 3}

Scanning electron photomicrographs showing preservation of Tertiary calcareous nannofossils from

Site 305 ( 0 to ca $52 \mathrm{~m}$ subbottom).

Figure 1 Proximal view of Coccolithus pelagicus (Wallich) with most of the proximal shield and minor parts of the distal shield removed by dissolution. $305-1-2,20 \mathrm{~cm}(1.70 \mathrm{~m}), \times 4000$.

Figure 2 Distal view of well-preserved proximal shield of Cyclococcolithus leptoporus (Murray and Blackman) whose distal shield has broken off, probably because of dissolution. $305-1-2,20 \mathrm{~cm}(1.70 \mathrm{~m})$, $\times 8250$.

Figure 3 Proximal view of dissociated distal shield of Cyclococcolithus leptoporus (Murray and Blackman). Dissolution has attacked the coccolith along sutures destroying a large part of the elements. 305-4-3, $40 \mathrm{~cm}(29.9 \mathrm{~m}), \times 7050$.

Figure 4 Distal view of Cyclococcolithus leptoporus (Murray and Blackman) showing minor overgrowth on a few strongly overlapping elements of the distal shield. $305-4-3,40 \mathrm{~cm}(29.9 \mathrm{~m}), \times 6700$.

Figure 5 Discoaster sp. which has accreted a large amount of secondary calcite forming thick overgrowths with euhedral crystal faces along the rays. Original bifurcation at the tip of the rays is still recognizable (arrow). 305-6-4, $92 \mathrm{~cm}(50.92 \mathrm{~m}), \times 5200$.

Figure 6 Discoaster sp. with one ray removed completely and others partly by dissolution. $305-6-4,92 \mathrm{~cm}(50.92 \mathrm{~m}), \times 5200$.

Figure $7 \quad$ Sphenolithus heteromorphus (?) Deflandre. The proximal shield has been removed entirely by dissolution. Faint overgrowth is visible on apical segments. $305-6-4,92 \mathrm{~cm}(50.92 \mathrm{~m}), \times 7700$.

Figure $8 \quad$ Sphenolithus distentus (Martini) whose branches have broken off. The proximal column and the rest of branch show overgrowths. $305-6-5,135 \mathrm{~cm}(52.35 \mathrm{~m}), \times 7550$.

Figure 9 A relatively well-preserved specimen of Reticulofenestra $\mathrm{sp}$. Notice absence of any welded elements. 305-6-4, $92 \mathrm{~cm}(50.92 \mathrm{~m}), \times 7750$.

Figure 10 Discoaster $\mathrm{sp}$. showing heavy overgrowth and perfect euhedral crystal faces. Dimples (arrow) are seen where overgrowth cement envelopes micrite particles (see also Wise, 1973, pl. 6, fig. 2). 305-6$5,135 \mathrm{~cm}(52.35 \mathrm{~m}), \times 7050$.

Figure 11 Sphenolithus moriformis (Brönnimann and Stradner) in oblique proximal view showing secondary calcite overgrowth and euhedral crystal faces on all elements. $305-6-5,135 \mathrm{~cm}(52.35 \mathrm{~m}), \times 9600$.

Figures 12,13 Proximal views of Ericsonia ovalis Black with a complete proximal shield in Figure 12 and a partly dissolved proximal shield in Figure 13. Also notice secondary calcite overgrowths, particularly on the proximal side of the distal shield and the central area in Figure 13. $305-6-5,135 \mathrm{~cm}(52.35 \mathrm{~m}), \times 4500$ and $\times 8000$. 
PLATE 3
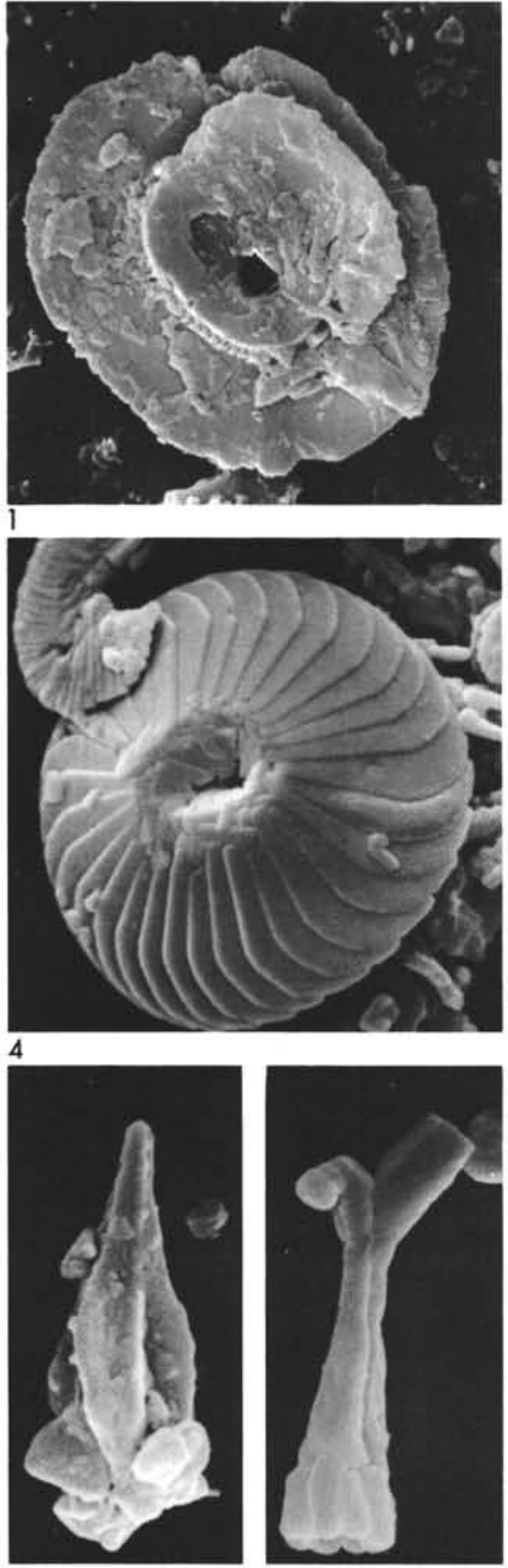

7

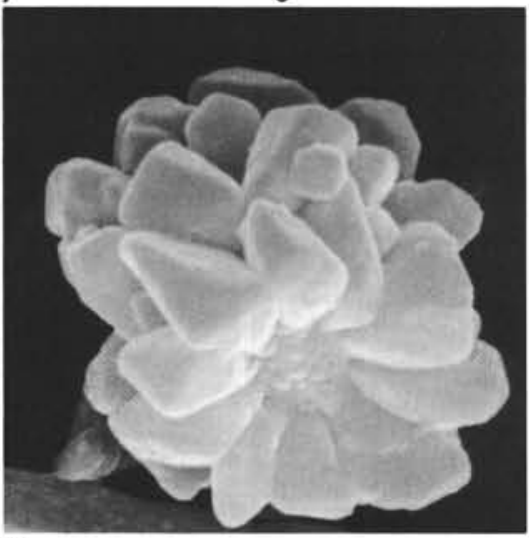

11

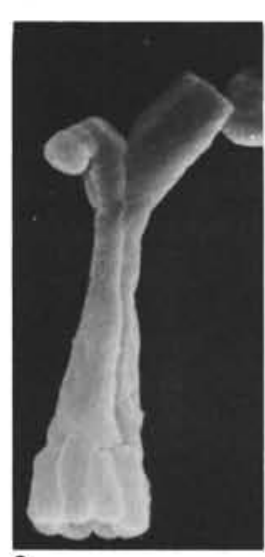

8
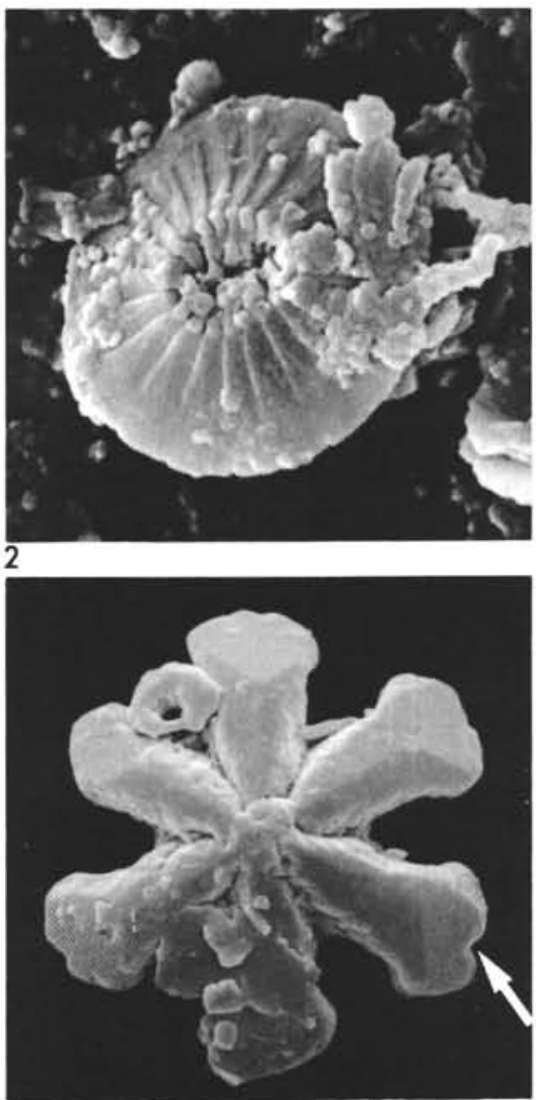

5

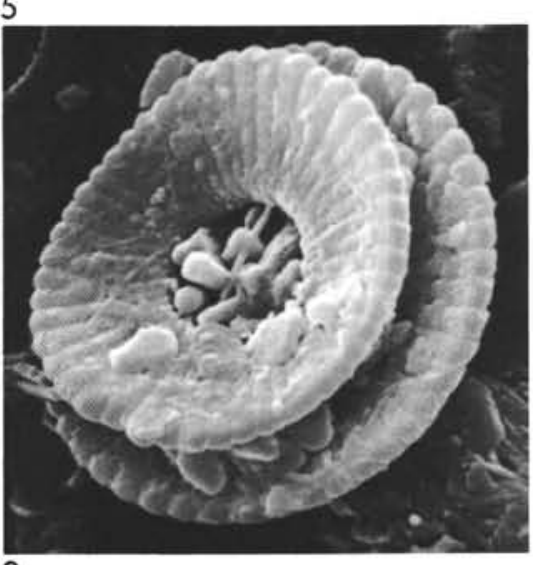

9

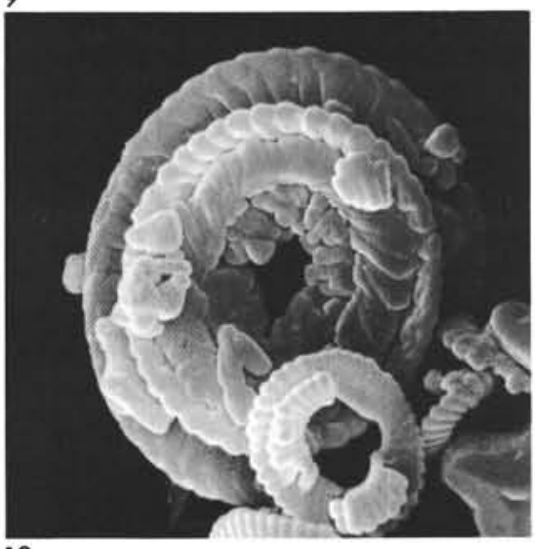

12

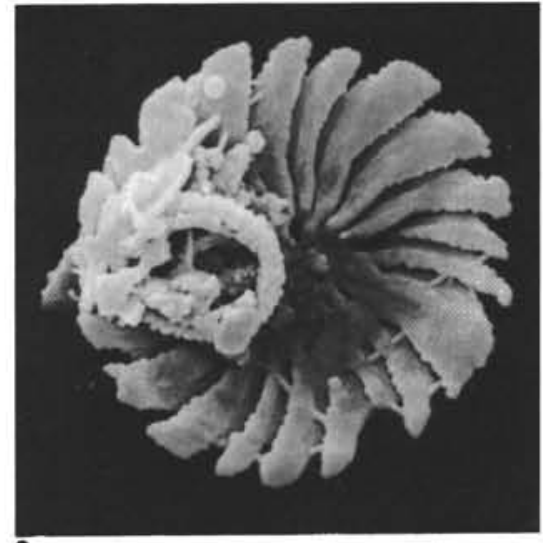

3

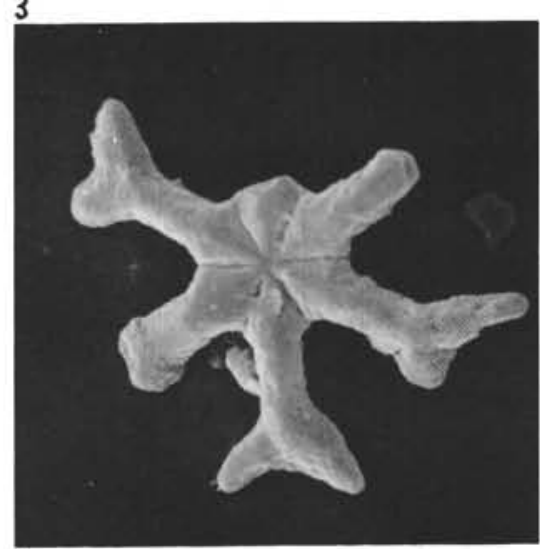

6
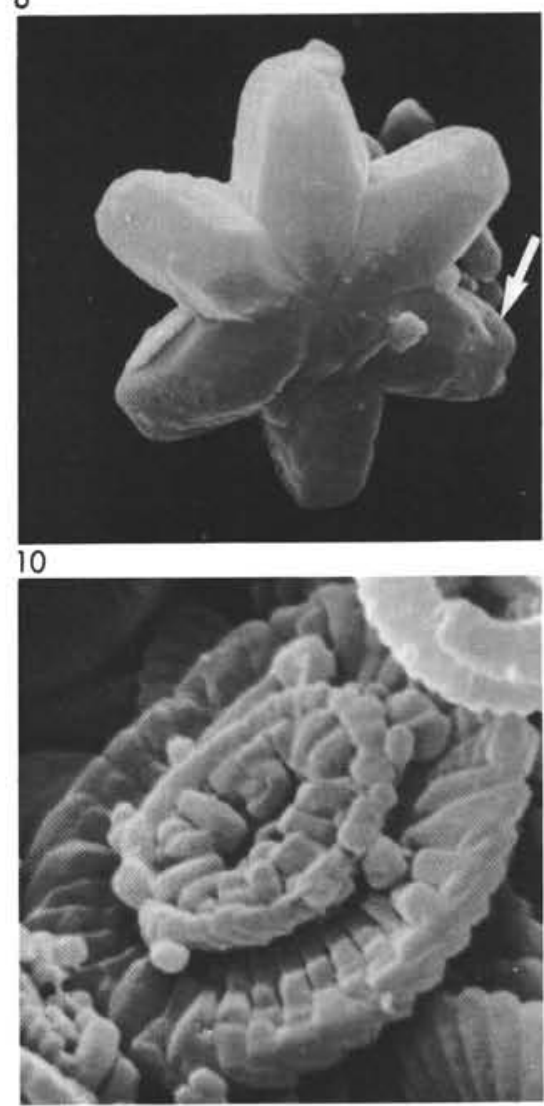

13 


\section{PLATE 4}

Scanning electron photomicrographs showing preservation of Paleogene calcareous nannofossils from

Site 305 (from 77 to $116 \mathrm{~m}$ subbottom).

Figure 1 Isthmolithus recurvus Deflandre, heavily coated by secondary calcite. Partly dissolved shields of coccoliths are also seen. 305-9-3, 100 $\mathrm{cm}(77.0 \mathrm{~m}), \times 6150$.

Figure 2 Discoaster sp. which has developed crystal faces along the rays due to secondary calcite deposition. The elements of a coccolith which are partly incorporated into the discoaster are good evidence for diagenetic overgrowth on the rays. $305-9-3,100 \mathrm{~cm}(77.0 \mathrm{~m})$, $\times 2950$.

Figure 3 Heavily overgrown Discoaster kuepperi Stradner, in proximal view showing considerably thickened rays with discrete euhedral crystal faces. 305-11-4, $90 \mathrm{~cm}(96.9 \mathrm{~m}), \times 6400$.

Figure 4 Distal view of Dictyococcites bisectus (Hay et al.). Some of the originally lath-shaped elements are blocky (arrow) due to accretion of secondary calcite. In the advanced stage all the elements of the central field show a blocky habit as shown by Wise (1973). 305-9-3, $100 \mathrm{~cm},(77.0 \mathrm{~m}), \times 3950$.

Figure 5 A Sphenolithus sp. almost completely overgrown. 305-11-4, $90 \mathrm{~cm}$ $(96.9 \mathrm{~m}), \times 3500$.

Figure $6 \quad$ Sphenolithus cf. Sphenolithus radians Deflandre with secondary calcite overgrowth on proximal, lateral and apical elements all of which show more or less discrete euhedral crystal faces. Notice also the isolated wall of Campylosphaera dela (Bramlette and Sullivan) whose central structure has been removed by dissolution (upper left). 305-11-4, $90 \mathrm{~cm}(96.9 \mathrm{~m}), \times 7000$.

Figure 7 Discoaster lodoensis Bramlette and Riedel usually has long and bent rays. The thick and stubby rays with euhedral faces seen on the specimen shown here indicate considerable dissolution prior to overgrowth. $305-11-4,90 \mathrm{~cm}(96.9 \mathrm{~m}), \times 4300$.

Figure 8 Distal view of Ericsonia ovalis s.l. showing heavy overgrowth on elements of the shield and the central area. $305-11-4,90 \mathrm{~cm}(96.9 \mathrm{~m})$, $\times 5900$.

Figure 9 Fractured surface of nanno ooze showing a late Paleocene assemblage including a fasciculith in side view and Ericsonia ovalis Black whose shields have been largely welded by deposition of calcite cement on most elements. 305-13-4, $90 \mathrm{~cm}(115.9 \mathrm{~m}), \times 4600$.

Figure 10 Proximal view of Ericsonia ovalis s.l. The distal shield is partly welded with the first cycle of the proximal shield. Both the first and second cycle are partly dissolved. 305-13-4, $90 \mathrm{~cm}(115.9 \mathrm{~m}), \times 7300$.

Figure 11 Proximal view of Chiasmolithus sp. with both shields intact. Ericsonia ovalis Black with partly dissolved proximal shield is seen in lower left. The sample is taken from a fracture surface of ooze. 305$13-4,90 \mathrm{~cm}(115.9 \mathrm{~m}), \times 2900$.

Figure 12 Discoaster multiradiatus Bramlette and Riedel showing differential growth of elements by accretion of secondary calcite. The sample is taken from a fracture surface of ooze. $305-13-4,90 \mathrm{~cm}(115.9 \mathrm{~m})$, $\times 3350$. 
PLATE 4
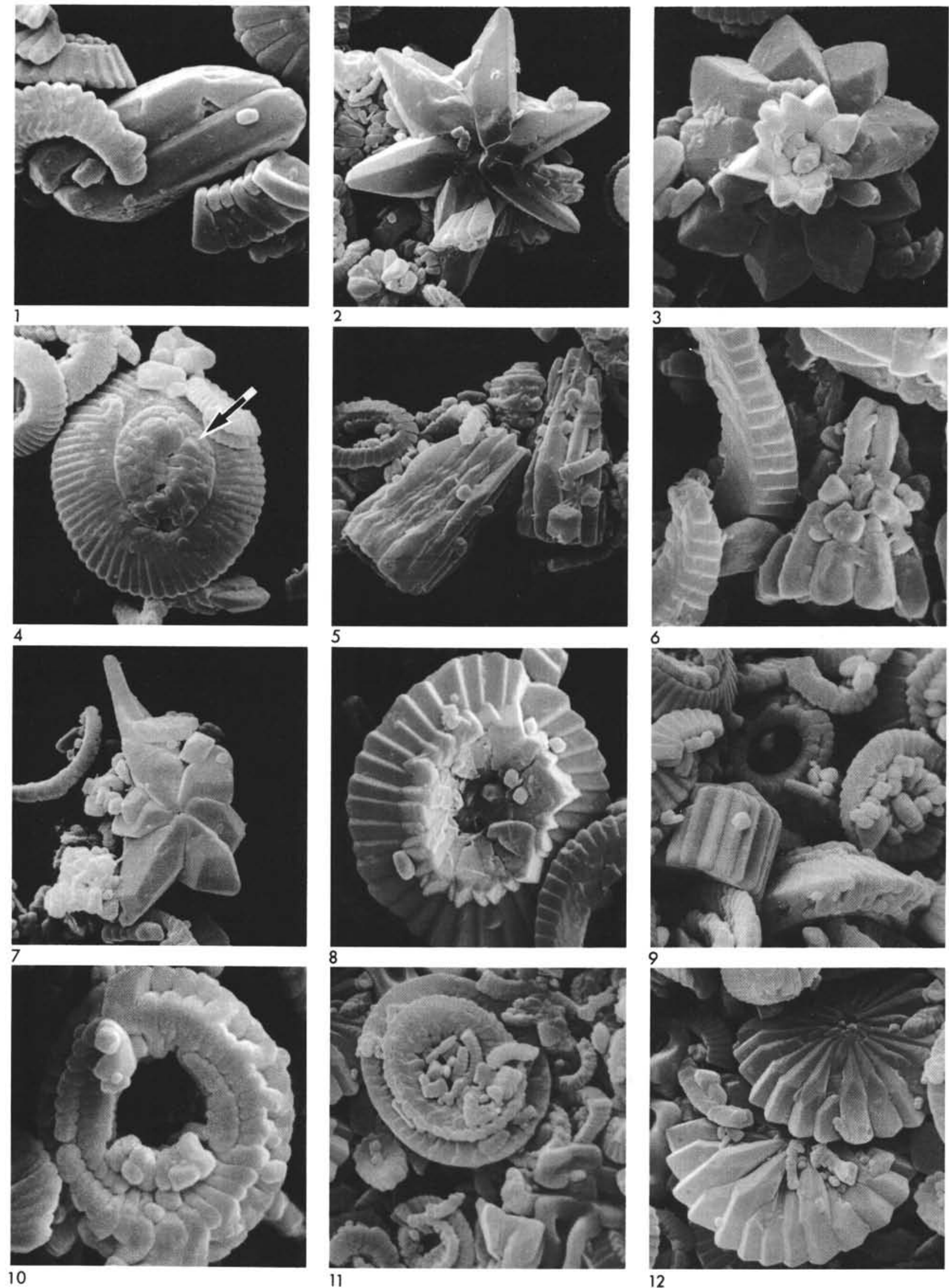


\section{PLATE 5}

Scanning electron photomicrographs showing preservation of Cretaceous calcareous nannofossils from Site 305 (from 145 to $599 \mathrm{~m}$ subbottom).

Figure $1 \quad$ Stradneria crenulata (Bramlette and Martini) with partly dissolved central area (arrow) and welded shields (arrow). 305-16-5, $23 \mathrm{~cm}$ $(145.23 \mathrm{~m}), \times 4100$.

Figure 2 Central process of Stradneria limbicrassa Reinhardt. The laths are fairly well preserved whereas the elements of the terminal structure are heavily overgrown and show crystal faces. 305-19-2, $130 \mathrm{~cm}$ $(169.8 \mathrm{~m}), \times 7500$.

Figure 3 Proximal view of Arkhangelskiella cymbiformis Vekshina displaying moderate overgrowth, mainly on the elements of the central structure. $305-19-2,130 \mathrm{~cm}(169.8 \mathrm{~m}), \times 7500$.

Figure $4 \quad$ Prediscosphaera cretacea (Arkhangelsky) in side view. The two shields are almost completely welded by accretion of cement on segments. 305-19-2, $130 \mathrm{~cm}(169.8 \mathrm{~m}), \times 7850$.

Figure $5 \quad$ Micula staurophora (Gardet), one of the most dissolution-resistant calcareous nannofossils in the Upper Cretaceous, is here moderately overgrown but still easily identified. Note fragments of coccoliths which are being incorporated into Micula. 305-19-2, $130 \mathrm{~cm}$ $(169.8 \mathrm{~m}) \times 6350$.

Figure $6 \quad$ Broinsonia parca (Stradner) in distal view showing blocky crystals on distal central structure indicating some of the originally lathshaped elements have accreted secondary calcite cement. 305-27, CC $(251.5 \mathrm{~m}), \times 4500$.

Figure 7 Terminal structure of a rhabdolith which has accreted a large amount of overgrowth calcite cement. Notice well-defined crystal faces and partly "digested" micrite grains and coccoliths. 305-27, CC $(251.5 \mathrm{~m}), \times 6800$.

Figure 8 Terminal structure of Prediscosphaera cretacea (Arkhangelsky) affected by overgrowth. 305-34, CC $(317.5 \mathrm{~m}), \times 6500$.

Figure $9 \quad$ Watznaueria barnesae (Black) (arrow) with minor dissolution and major overgrowth features. Dissolution has caused disaggregation of most coccoliths whose segments occur now as partly overgrown euhedral micrite grains. 305-34, CC, $\times 5050$.

Figure 10 Fracture surface of limestone showing pore filling neomorphic euhedral calcite growing on and enveloping coccoliths (lower side) and thereby partly incorporating other smaller coccoliths (arrow). $305-59-1,140 \mathrm{~cm}(551.9 \mathrm{~m}), \times 5250$.

Figure 11 Coccolith affected by dissolution (center) and relatively large neomorphic euhedral calcite crystals which have grown into pore space. The sample is taken from a fracture surface of limestone. $305-59-1,140 \mathrm{~cm}(551.9 \mathrm{~m}), \times 6350$.

Figure 12 A neomorphic calcite crystal which has incorporated a coccolith. A trace of sutures of coccolith are still seen on crystal surface. 305-59$1,140 \mathrm{~cm}(551.9 \mathrm{~m}), \times 7900$.

Figure 13 Central process of Eiffellithus turriseiffeli-type showing dissolution of faintly overgrown laths. $305-64-1,100 \mathrm{~cm}(559.0 \mathrm{~m}), \times 8600$. 
PLATE 5
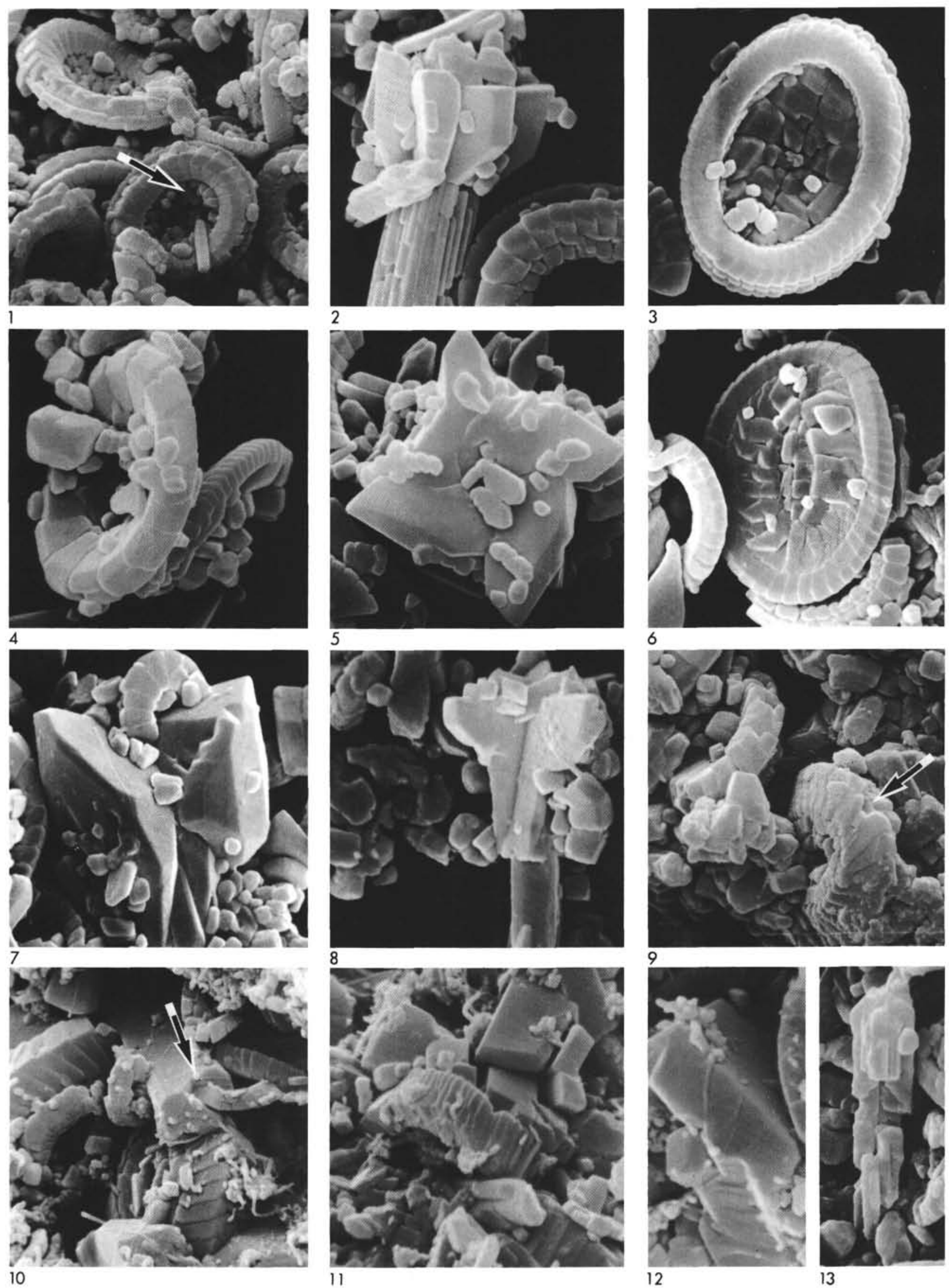


\section{PLATE 6}

Scanning electron photomicrographs showing preservation of Cretaceous nannofossils from

Site 306.

Figures 1, 3 Siliceous framework of a calcareous porcellanite which has been treated with hydrochloric acid to dissolve away the carbonate. Calcitic fossils and particles are therefore seen as molds. Notice in Figure 1 the mold of Watznaueria barnesae (Black) and partly silicified rhabdolith of the Eiffellithus turriseiffeli-type. In Figure 3 a similar rhabdolith is seen whose central canal is filled with silica. Both figures from Sample 306-8-1, $38 \mathrm{~cm}$ (113.38 $\mathrm{m}), \times 6900$ and $\times 9450$.

Figures 2, 4-8 Fracture surfaces of calcareous porcellanites showing molds of coccoliths in the siliceous groundmass. Some of these molds may have formed during sample preparation, hence are replicas, however, others are real. Molds of complete distal parts of Watznaueria barnesae (Black) are seen in Figures 2, 4, and 8. Notice the mold of an internal part of a coccolith in Figure 7 (arrow). Apparently dissolution has affected the carbonate particles both before and after cementation (see text).

2, 6. $306-8-1,38 \mathrm{~cm}(113.38 \mathrm{~m}), \times 3450, \times 6900$.

4. $306-3, \mathrm{CC}(28.0 \mathrm{~m}), \times 7000$.

5. $306-6-1,114 \mathrm{~cm}(76.64 \mathrm{~m}), \times 3450$.

7, 8. 306-10-1, $69 \mathrm{~cm}(151.7 \mathrm{~m}), \times 6940$ and $\times 3470$.

Figures 9,10 A fracture surface of chalk. In Figure 9 large crystal is seen which has grown by deposition of overgrowth cement on a nannofossil and pressure solution between a coccolith and a rhabdolith (arrow). 306-24-1, $140 \mathrm{~cm}(310.4 \mathrm{~m}), \times 8000$. Figure 10 also shows large pore-filling crystals enveloping coccoliths as well as Watznaueria barnesae (Black) in different preservation states. 306-29, CC $(365.0 \mathrm{~m}), \times 6940$.

Figure 11 The surface of twinned dolomite crystals is shown in Plate 2, Figure 6. Relatively well-preserved coccoliths appear like half-drowned flotsam on the dolomite surface. 306-26, CC $(337.0 \mathrm{~m}), \times 426$. 
PLATE 6
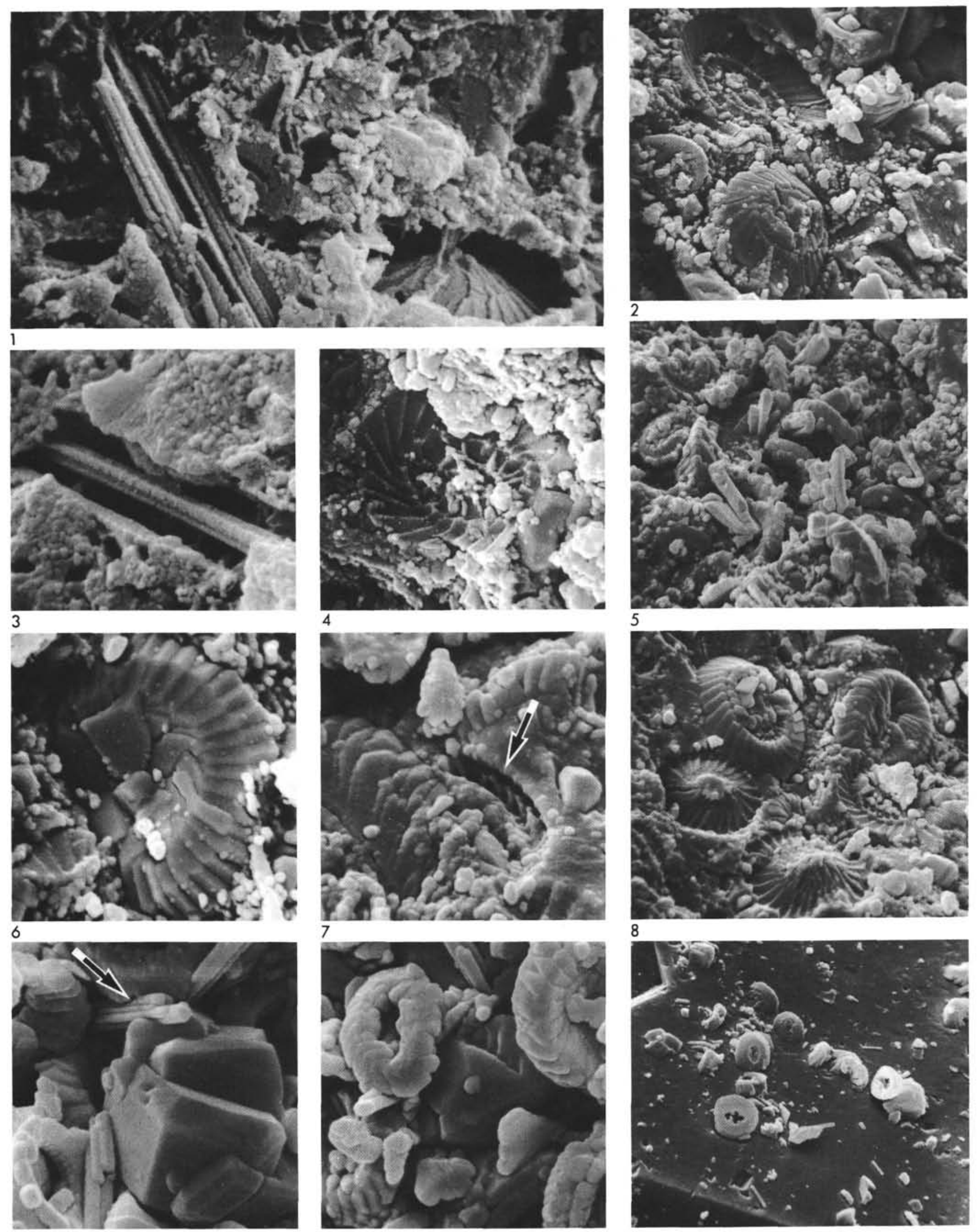


\section{PLATE 7}

Scanning electron photomicrographs showing different stages of preservation of Watznaueria barnesae (Black) in samples from Site 305.

Figures 1,2 In Figure 1 elements of the shield and central areas of Coccospheres have accreted secondary calcite cement. $\times 7600$. In Figure 2 the distal elements of the central field have been removed by dissolution. $\times 11700$. Both figures are from $305-27$, CC $(251.5$ $\mathrm{m})$.

Figures 3-5 Proximal views showing different steps of deposition of calcite cement leading to progressive welding of shields and infilling of central area. $305-27$, CC $(251.5 \mathrm{~m}), \times 8900 ; 305-46, \mathrm{CC}(438.0$ $\mathrm{m}) . \times 7250$; and $305-64-1,100 \mathrm{~cm}(599.0 \mathrm{~m})$, $\times 8950$; respectively.

Figure 6 Distal view showing moderate overgrowth on elements of shield and central structure. 305-19-2, $130 \mathrm{~cm}(169.8 \mathrm{~m}), \times 7300$.

Figure 7 Distal view showing moderate overgrowth on segments of shield whereas fine elements of central structure have been dissolved. 305-34, CC (317.5 $\mathrm{m}), \times 7850$.

Figure 8 Distal view showing overgrowth on shield and central structure. 305-64-1, $100 \mathrm{~cm}(599.0 \mathrm{~m})$, $\times 7650$. 
PLATE 7
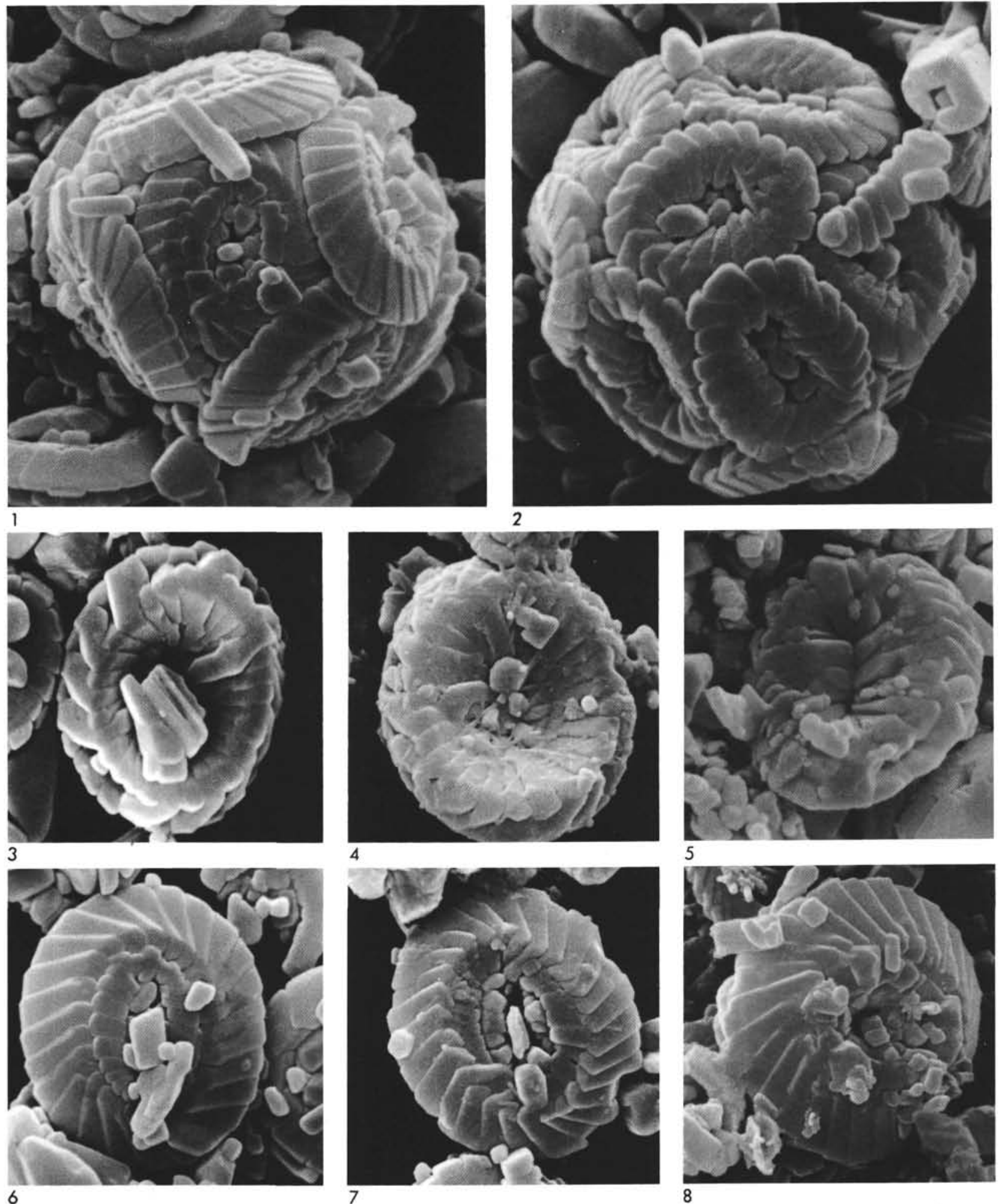